OPEN ACCESS

Edited by:

Persephone Borrow,

University of Oxford,

United Kingdom

Reviewed by:

Maria Raffaella Zocchi,

Scientific Institute San Raffaele, Italy

Paul Urquhart Cameron,

University of Melbourne, Australia

*Correspondence:

Bin Su

binsu.paris7@hotmail.com:

Tong Zhang

zt_doc@163.com

tThese authors have contributed equally to this work.

Specialty section: This article was submitted to HIV and AIDS,

a section of the journal

Frontiers in Immunology

Received: 14 May 2017 Accepted: 03 August 2017 Published: 21 August 2017

Citation:

Li Z, LUX, Hu Z, Luo Z, Jiang W,

Wu H, Gao Y, Yan J, Zhang Q,

Song A, Huang X, Mou D, Su B and

Zhang T (2017) Syphilis Infection Differentially Regulates the Phenotype and Function of $\gamma \delta T$ Cells in

HIV-1-Infected Patients Depends on the HIV-1 Disease Stage.

Front. Immunol. 8:991.

doi: 10.3389/fimmu.2017.00991

\section{Syphilis Infection Differentially Regulates the Phenotype and Function of $\gamma \delta$ T Cells in HIV-1-Infected Patients Depends on the HIV-1 Disease Stage}

\author{
Zhen $\mathrm{Li}^{1+}$, Xiaofan $\mathrm{Lu}^{1+}$, Zhiliang $\mathrm{Hu}^{2}$, Zhenwu $\mathrm{Luo}^{3}$, Wei Jiang ${ }^{3,4}$, Hao $\mathrm{Wu}^{1}$, Yanqing $\mathrm{GaO}^{5}$, \\ Junling Yan ${ }^{5}$, Qiuyue Zhang ${ }^{1}$, Aixin Song ${ }^{1}$, Xiaojie Huang', Danlei Mou', Bin Su'* \\ and Tong Zhang ${ }^{1 *}$

\begin{abstract}
${ }^{1}$ Beijing Key Laboratory for HIV/AIDS Research, Center for Infectious Diseases, Beijing You'an Hospital, Capital Medical University, Beijing, China, ${ }^{2}$ Department of Infectious Diseases, The Second Affiliated Hospital, Southeast University, Nanjing, China, ${ }^{3}$ Department of Microbiology and Immunology, Medical University of South Carolina, Charleston, SC, United States, ${ }^{4}$ Division of Infectious Diseases, Department of Medicine, Medical University of South Carolina, Charleston, SC, United States, ${ }^{5}$ Department of Dermatology, Center for Infectious Diseases, Beijing You'an Hospital, Capital Medical University, Beijing, China
\end{abstract}

A rapidly escalating outbreak of syphilis infection has been affected men who have sex with men, particularly those with HIV-1 infection. $\gamma \delta$ T cells are unconventional immune cells with two main subsets, V $\delta 1 T$ cells and V $\delta 2 T$ cells, which possess a combination of innate and adaptive immune features allowing them against HIV-1. However, whether syphilis infection affects the phenotype and function of $\gamma \delta \mathrm{T}$ cells in HIV-1-infected patients remains unclear, especially in acute HIV-1 infection (AHI). In this study, we enrolled $57 \mathrm{HIV}$-1-infected patients (24 with HIV-1 infection only and 33 coinfected with syphilis) from an acute HIV-1-infected cohort in Beijing (PRIMO). A comprehensive analysis of $\gamma \delta$ T-cell phenotype and function was performed by flow cytometry. We found syphilis coinfection could reverse the imbalance of V $\delta 1 / \mathrm{V} \delta 2$ ratio in AHI. Syphilis infection results in decreased $\gamma \delta \mathrm{T}$-cell activation in $\mathrm{AHI}$, but increased $\gamma \delta$ T-cell activation in chronic HIV-1 infection (CHI). Moreover, patients with $\mathrm{CHI}$ had larger numbers of IL-17-producing $\gamma \delta T$ cells than those with AHI, regardless of syphilis status. Thus, syphilis affected the $\gamma \delta$ T-cell immune response differently in patients depending on the stages of HIV-1 disease. In addition, the percentage of IL-17-producing $\gamma \delta \mathrm{T}$ cells was positively correlated with the percentage of neutrophils. These results suggest that the $\gamma \delta$ T-cell/IL-17/neutrophil axis is involved in HIV-1 pathogenesis and disease progression. Taken together, our observations provide new insight into the roles of $\gamma \delta$ T cells in immunopathogenesis of syphilis and HIV-1 coinfection, particularly during $\mathrm{AHI}$, and our findings may be helpful for the prevention of syphilis and other sexually transmitted infections and highlight the great significance on the remedy of patients coinfected with HIV-1.

Keywords: syphilis, acute/chronic HIV-1 infection, $\gamma \delta$ T cells, innate immune response, IL-17 


\section{INTRODUCTION}

Syphilis is a chronic bacterial infection caused by the sexually transmitted pathogen, Treponema pallidum. The incidence of syphilis has increased sharply in recent years in men who have sex with men (MSM), especially those with HIV-1 infection (1-7). Syphilis worsens disease progression in HIV-1-infected patients, as demonstrated by $\mathrm{CD} 4^{+} \mathrm{T}$-cell depletion and increased plasma HIV-1 RNA levels (8-10). Syphilis may also increase the risk of HIV-1 infection and transmission in MSM population $(11,12)$. Meanwhile, HIV-1 infection may effect on the presentation, disease progression, and efficacy of treatment on syphilis (13). The host immune system plays a key role in controlling HIV-1 disease progression through host restriction factors (TRIMs, APOBEC3G, SAMHD1), cytokines (IL-6, IFN- $\gamma$, TNF- $\alpha$ ), and chemokines (MIP- $1 \alpha$, MIP-1 $\beta$, RANTES) (14-18). Cells producing IL-17 and IFN- $\gamma$ have been implicated in inflammation and central nervous system damages $(19,20)$. However, the cellular immune responses elicited by HIV-1 and syphilis coinfection have not been well studied.

$\gamma \delta \mathrm{T}$ cells account for only a small proportion (1-10\%) of $\mathrm{T}$ lymphocytes, but are nevertheless a critical component of the innate immune system and play important roles in the first line (21). Human $\gamma \delta \mathrm{T}$ cells have been defined into two main subsets, $\mathrm{V} \delta_{1} \mathrm{~T}$ cells and $\mathrm{V} \delta_{2} \mathrm{~T}$ cells. $\mathrm{V} \delta_{1} \gamma \delta \mathrm{T}$ cells are located predominantly in the mucosae, where they recognize stress-induced molecules (such as ULBPs and MICA/B), and play a protective role. By contrast, $\mathrm{V}_{2} \gamma \delta \mathrm{T}$ cells recognize phosphoantigens (such as IPP). They account for most of the circulating $\gamma \delta \mathrm{T}$ cells in the bloodstream and are directed against tumors and infectious diseases. In the peripheral blood, $\mathrm{V}_{1} \mathrm{~T}$ cells, also known as regulatory $\gamma \delta$ $\mathrm{T}$ cells, play an immunosuppressive role, through Foxp3 expression or the secretion of cytokines, such as TGF- $\beta$ and IL-10 (22). On the contrary, $\mathrm{V \delta}_{2} \mathrm{~T}$ cells mainly served as a control of antiviral immunity; cytotoxic cells kill tumor cells or pathogen-infected cells by secreting cytokines, perforin, granzyme $\mathrm{B}$, or through FasFasL pathway; antigen presentation; or B helper T-cell function $(21,23,24)$. HIV-1 infection strongly depletes the numbers of $\mathrm{V}_{2} \mathrm{~T}$ cells and induces $\mathrm{V}_{2}$ T-cell anergy, resulting in weaker responses to IPP stimulation (25). In our previous study, we found that $\gamma \delta \mathrm{T}$ cells were over-activated in HIV-1 infection and were associated with HIV-1 disease progression (26). IL-17producing $\gamma \delta \mathrm{T}$ cells increased in HIV-1-infected patients with fast disease progression and were involved in HIV-1 pathogenesis (26). However, to our knowledge, there are few studies describing the antisyphilitic role of $\gamma \delta \mathrm{T}$ cells in HIV-1 infection. In addition, increasing IFN- $\gamma / \mathrm{IL}-17$-producing $\mathrm{CD} 8^{+} \mathrm{T}$ cells were considered as a compensation in $\mathrm{HIV}^{+}$individuals, but they were not sufficient to eliminate the spirochete (27). Therefore, we propose that $\gamma \delta \mathrm{T}$ cells involved in cell-mediated antisyphilitic response in HIV-1-infected patients. However, how the phenotype and function of $\gamma \delta \mathrm{T}$ cells in HIV-1-infected patients with syphilis coinfection change remains unclear, especially in acute HIV-1 infection (AHI).

In the current study, we performed a comprehensive analysis of $\gamma \delta$ T-cell phenotype and function in patients coinfected with syphilis and HIV-1. We found that syphilis affected the phenotype and function of $\gamma \delta$ T cells differently in HIV-1-infected patients, depending on the stages of HIV-1 disease. Our observations provide new insight into the roles of $\gamma \delta \mathrm{T}$ cells in immunopathogenesis of syphilis and HIV-1 coinfection. These findings suggest syphilis monitoring, follow-up, and treatment in MSM or HIV-1-positive individuals should be enhanced.

\section{MATERIALS AND METHODS}

\section{Study Subjects}

Study subjects used in this study were enrolled from the Beijing PRIMO Clinical Cohort, a prospective study cohort of HIV-1-negative MSM to identify AHI at Beijing You'an Hospital, Beijing, China, since October 2006 (28). After enrollment, they were screened for plasma HIV-1 antibody, HIV-1 RNA level, clinical signs of acute infection, and syphilis status. Then they were followed up every 2 months, and HIV-1 antibody and syphilis were detected at each visit. AHI was defined as a negative or indeterminate HIV-1 antibody status but a positive HIV RNA (29). Once acute HIV-1-infected cases were identified, patients were followed up at 1, 2, 4, 8, and 12 weeks, and then every 3 months and syphilis status was monitored at each visit (Figure 1). Blood samples were collected, and peripheral blood mononuclear cells (PBMCs) and plasma were isolated and cryopreserved. Estimated date of infection was defined as the mid-point between the last HIV-1 antibody negative test and the first HIV-1 antibody positive test, or as 14 days prior to a positive RNA PCR assay on the same day as a negative HIV Enzyme Immunoassay. Patients whose infection time was longer than 180 days were defined as chronic HIV-1 infection (CHI). $26 \mathrm{AHI}$ and $31 \mathrm{CHI}$ patients were recruited randomly. The estimated infection date of AHI and CHI patients were $62 \pm 33$ and $565 \pm 307$ days, respectively. Early HIV-1 infection can be depicted as six discrete stages proposed by Fiebig et al. (30, 31). Stage I-II: HIV-1 RNA positive, ELISA negative with 3 patients; stage III-IV: HIV-1 RNA positive, ELISA positive, and Western blot negative or indeterminate with 4 patients; stage V-VI: HIV-1 RNA positive, ELISA positive, Western blot without/with p31 band with 19 patients. Syphilis was diagnosed on the basis of a compatible history, and the results of rapid plasma reagin (RPR) test (Shanghai Kehua Company, China) and T. pallidum particle agglutination assay (TPPA) (Fujirebio Diagnostics, Inc., Japan) (32). Based on the RPR and TPPA results, AHI and CHI patients were, divided into $\mathrm{HIV}^{+} \mathrm{RPR}^{+}$group $(n=15$, $n=18)$ and $\mathrm{HIV}^{+} \mathrm{RPR}^{-}$group $(n=11, n=13)$, respectively. All AHI and CHI patients were ART-naïve treated. 6 patients in acute $\mathrm{HIV}^{+} \mathrm{RPR}^{+}$group and 4 patients in chronic $\mathrm{HIV}^{+} \mathrm{RPR}^{+}$ group received benzathine benzylpenicillin treatment for syphilis before their enrollment in this study. Patients with opportunistic infections or coinfections with tuberculosis, hepatitis B virus, or hepatitis $C$ virus were excluded. Twenty age-matched male MSM HIV-1-negative controls (HC) were included as controls. The characteristics of all subjects are described in the Table 1.

This study and all relevant experiments have been approved by the Beijing You'an Hospital Research Ethics Committee and written informed consent was obtained from each participant 


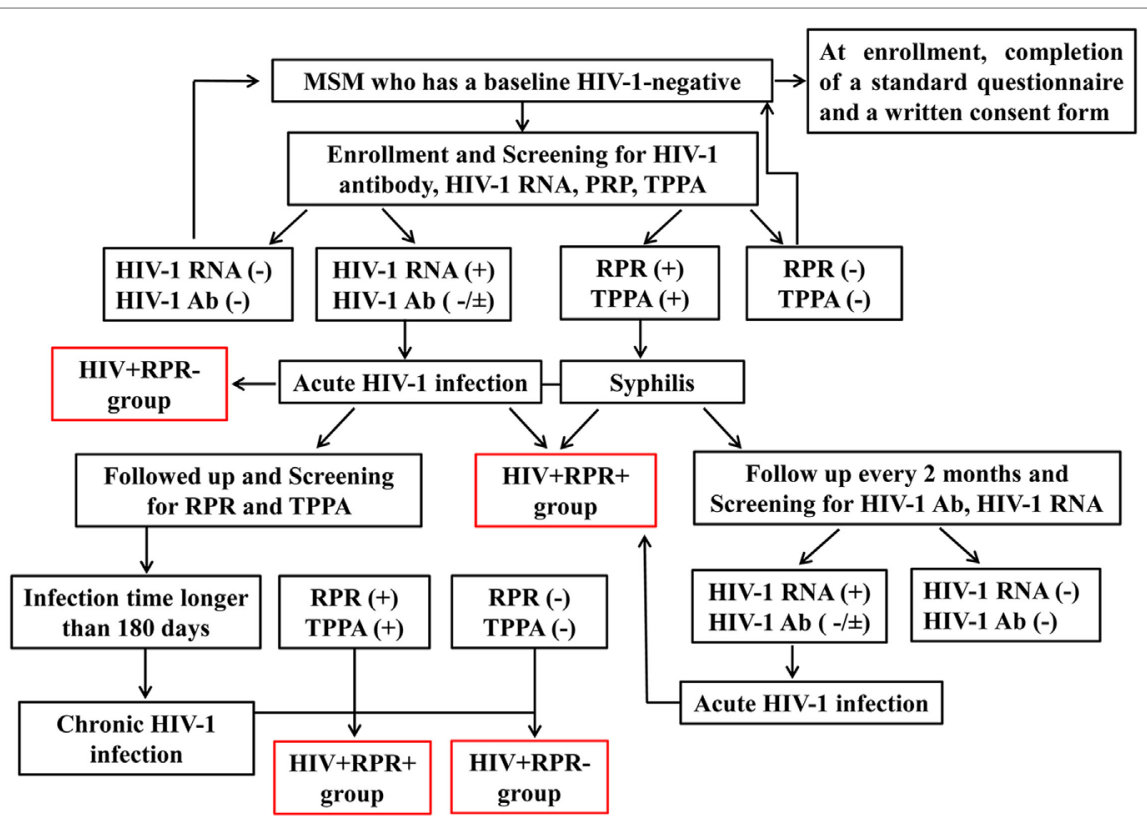

FIGURE 1 | The flow chart summarizing the enrollment of subjects in the study. HIV-1-negative men who have sex with men (MSM) were enrolled in a prospective cohort study to identify acute HIV-1 infection. At enrollment, participants were screened for HIV-1 infection and syphilis by detecting HIV-1 RNA, HIV-1 antibody, rapid plasma reagin (RPR), and T. pallidum particle agglutination assay (TPPA) respectively. Then they were followed up every 2 months and HIV-1RNA, HIV-1 antibody, RPR, and TPPA were tested at each visit. Once acute HIV-1-infected individuals were captured, they continued to be followed up to 2-3 years to observe the natural progression of HIV-1 infection. According to the Fiebig stage, when the estimate date of infection was longer than 180 days, it is considered as a chronic $\mathrm{HIV}$-1 infection. Acute or chronic HIV-1-infected patients with $\mathrm{RPR}^{+}$were separated into $\mathrm{HIV}^{+} \mathrm{RPR}^{+}$group in acute or chronic infection. Otherwise, they were enrolled into HIV+RPR- group in acute or chronic infection.

TABLE 1 | Basic characteristics of all participants enrolled in this study.

\begin{tabular}{|c|c|c|c|c|c|c|c|}
\hline \multirow[t]{2}{*}{ Characteristics } & \multirow[t]{2}{*}{ Healthy control } & \multicolumn{2}{|c|}{ Acute HIV-1 infection } & \multirow[t]{2}{*}{$P$-value } & \multicolumn{2}{|c|}{ Chronic HIV-1 infection } & \multirow[t]{2}{*}{$P$-value } \\
\hline & & $\mathbf{R P R}^{+}$ & $\mathbf{R P R}^{-}$ & & $\mathbf{R P R}^{+}$ & $\mathbf{R P R}^{-}$ & \\
\hline Cases & 20 & 15 & 11 & & 18 & 13 & \\
\hline Chinese Han population (\%) & 100 & 100 & 100 & & 100 & 100 & \\
\hline Age (years) & $29.5 \pm 7.7$ & $31.5 \pm 6.8$ & $30.3 \pm 7.5$ & 0.678 & $34.6 \pm 7.6$ & $33.6 \pm 8.8$ & 0.703 \\
\hline Infection time (day) & NA & $58.6 \pm 23.8$ & $66.6 \pm 43.8$ & 0.917 & $500.9 \pm 249.4$ & $655.4 \pm 364.1$ & 0.483 \\
\hline $\mathrm{CD}^{+}$T-cell count (cells/ $\left.\mu \mathrm{l}\right)$ & $1751 \pm 467$ & $1622 \pm 499$ & $1545 \pm 537$ & 0.958 & $1801 \pm 846$ & $1629 \pm 394$ & 0.857 \\
\hline CD4+ T-cell count (cells/ $\mu$ l) & $865 \pm 300^{\star \star}$ & $423 \pm 150$ & $438 \pm 144$ & 0.815 & $415 \pm 118$ & $521 \pm 143$ & 0.097 \\
\hline 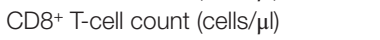 & $824 \pm 291$ & $1173 \pm 503$ & $1024 \pm 396$ & 0.716 & $1072 \pm 558$ & $1070 \pm 397$ & 0.561 \\
\hline CD4:CD8 ratio & $1.13 \pm 0.55^{\star \star}$ & $0.38 \pm 0.22$ & $0.49 \pm 0.23$ & 0.203 & $0.37 \pm 0.27$ & $0.56 \pm 0.32$ & 0.063 \\
\hline Plasma viral load (log10 copies/ml) & NA & $4.45 \pm 0.74$ & $4.66 \pm 1.15$ & 0.978 & $4.27 \pm 0.88$ & $3.86 \pm 0.69$ & 0.267 \\
\hline
\end{tabular}

Data were presented as mean $\pm S D$.

${ }^{* *} P<0.001$, compared with HIV-1-infected patients.

$P$ values were determined by Mann-Whitney test.

$N A$, not applicable; RPR, rapid plasma reagin.

according to the Declaration of Helsinki. All the participants provided written informed consent for their information, and clinical samples were stored and used for research. At enrollment, all subjects provided baseline demographic, clinical, and epidemiological information by completing a standardized questionnaire. The methods were carried out in accordance with approved guidelines and regulations.

\section{Whole-Blood Analysis}

Venous blood was collected into tubes containing EDTA as an anticoagulant. Whole blood cells analysis was performed on
Uritest-3000 Fully Automated Hematology Analyzer (URIT medical electronic company, Shenzhen, China). Absolute counts of $\mathrm{CD}^{+}, \mathrm{CD}^{+}$, and $\mathrm{CD}^{+} \mathrm{T}$ lymphocytes were obtained as previously described (26).

\section{Viral Load Testing}

Plasma HIV-1 viral load (copies/ml) were quantified using the COBAS AmpliPrep/COBAS TaqMan 48 Analyser (Roche Diagnostic, Branchburg, NJ, USA), or by real-time PCR (Abbott, Des Plaines, IL, USA), with a detection limit of 40 copies $/ \mathrm{ml}$ of plasma. 


\section{Serological Assays}

HIV-1 infection status was determined by screening with a HIV$1 / 2$ antigen/antibody combo enzyme immunoassay (Beijing Wantai Biological Medical Company, Beijing, China). Positive specimens were further conformed by using Western blot for HIV-1/2 (HIV Blot 2.0 MP Diagnostics, Singapore). The diagnosis of syphilis was performed with the RPR test (Shanghai Kehua Company, China) and TPPA (Fujirebio Diagnostics, Inc., Japan) (32). A seropositive result for TPPA was defined as the presence of a past or current syphilis infection, while a seropositive result for both TPPA and RPR was diagnosed as a current syphilis infection.

\section{Antibodies}

Phycoerythrin (PE)-conjugated anti-human CD38 (HIT2) monoclonal antibody (mAb), allophycocyanin (APC)conjugated anti-human HLA-DR (L243) mAb, phycoerythrincyanine 7 (PE-cy7)-conjugated anti-human CD3 (HIT3a) $\mathrm{mAb}$, peridinin-chlorophyll protein complex cyanine 5.5 (PerCP-cy5.5)-conjugated anti-human CD27 (O323) mAb, and APC-conjugated anti-human CD45RA (HI100) mAb were purchased from Biolegend (San Diego, CA, USA). Fluorescein isothiocyanate (FITC)-conjugated anti-human pan TCR $\gamma \delta \mathrm{mAb}$, PE-conjugated anti-human pan TCR $\gamma \delta$ (IMMU510) $\mathrm{mAb}$ and FITC-conjugated anti-human pan $\mathrm{V}_{2} \mathrm{TCR}$ mAb (IMMU389) were purchased from Immunotech (Beckman Coulter, Fullerton, France). FITC-conjugated anti-human panV $\delta_{1}$ TCR (TS8.2) mAb was purchased from Pierce (Rockford, IL, USA). PE-conjugated IL-17A (SCPL1362) $\mathrm{mAb}$ and APC-conjugated interferon- $\gamma$ $(\mathrm{IFN}-\gamma)(\mathrm{B} 27) \mathrm{mAb}$ were purchased from BD Pharmingen (San Diego, CA, USA). The isotype control $\mathrm{mAbs}$ were purchased from the corresponding companies.

\section{Flow Cytometry}

For surface staining, PBMCs were isolated from HC and HIV1 -infected patients with or without syphilis infection. Cells were washed with $1 \%$ bovine serum albumin in PBS and were labeled with LIVE/DEAD fixable viability stain 510 (BD Biosciences, San Jose, CA, USA), and dead cells were excluded. Then, cells labeled with specific surface antibodies: gating strategy on $\mathrm{CD}^{+} \gamma \delta \mathrm{TCR}^{+}$ cells, $\mathrm{V}_{1}$ and $\mathrm{V} \delta_{2} \mathrm{~T}$ cells, or $\gamma \delta \mathrm{T}_{\text {Naive }}\left(\mathrm{CD} 27^{+} \mathrm{CD} 45 \mathrm{RA}^{+}\right), \gamma \delta \mathrm{T}_{\mathrm{CM}}$ $\left(\mathrm{CD} 27^{+} \mathrm{CD} 45 \mathrm{RA}^{-}\right), \quad \gamma \delta \mathrm{T}_{\mathrm{EM}}\left(\mathrm{CD} 27^{-} \mathrm{CD} 45 \mathrm{RA}^{-}\right)$, and $\gamma \delta \mathrm{T}_{\mathrm{EMRA}}$ $\left(\mathrm{CD} 27^{-} \mathrm{CD}^{2} 5 \mathrm{RA}^{+}\right)$were displayed (Figure 2). Cytometer setup

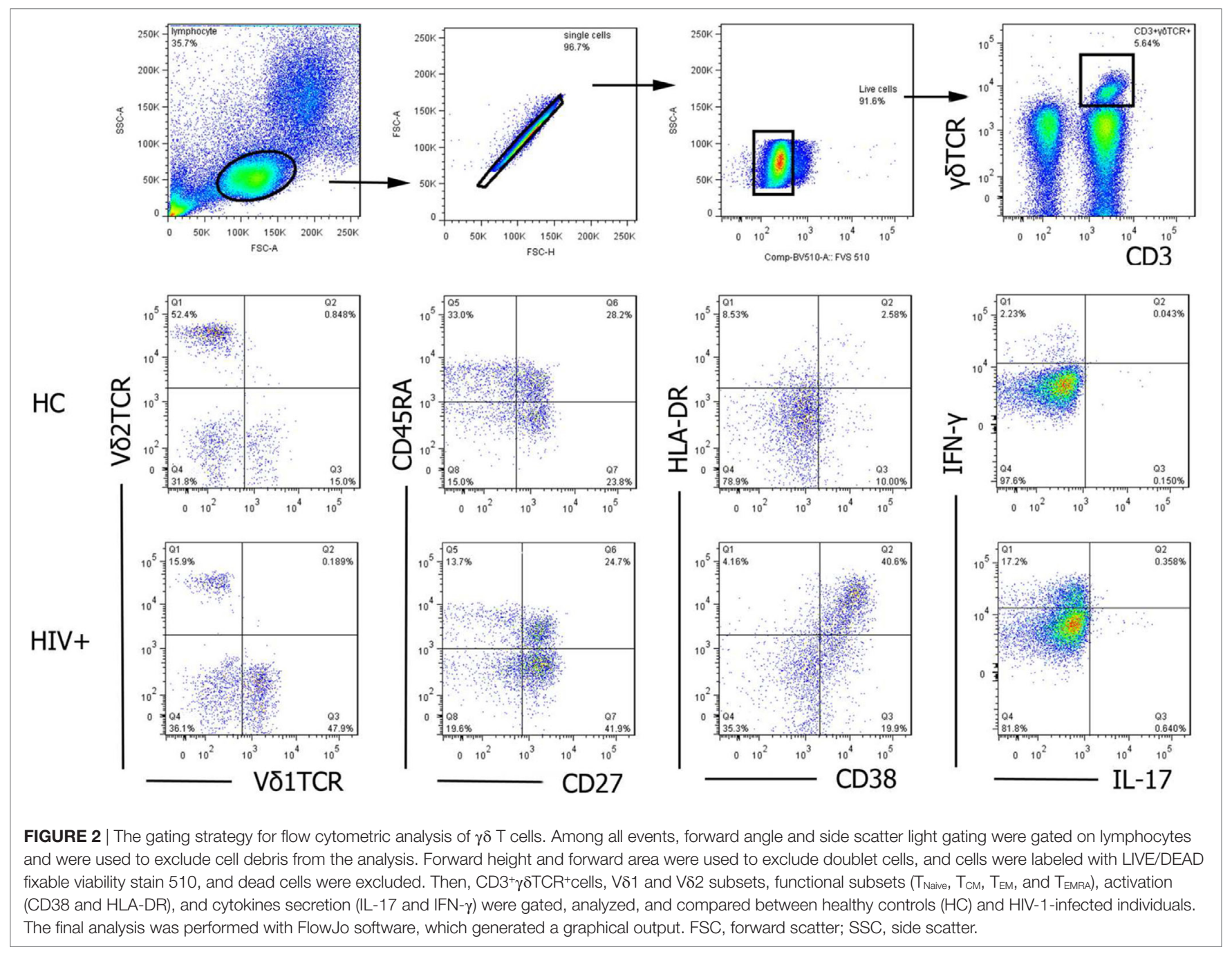


and tracking calibration particles were used to ensure that fluorescence intensity measurement was consistent in all experiments. Flow cytometry Comp-Beads kits (BD Biosciences, San Jose, CA, USA) were used for compensation. Forward angle and side scatter light gating were gated on lymphocytes and were used to exclude cell debris from the analysis. Forward height and forward area were used to exclude doublet cells. Cells were performed with a FACScan flow cytometer, as previously described $(33,34)$. The final analysis was performed with FlowJo software (version 7.6.2; Tree Star Inc., Ashland, OR, USA), which generated a graphical output. The strategies for the analysis of flow cytometry data are detailed in Figure 2.

\section{Intracellular Staining}

Peripheral blood mononuclear cells were incubated with $50 \mathrm{ng} / \mathrm{ml}$ phorbol 12-myristate-13-acetate (PMA), $1 \mu \mathrm{g} / \mathrm{ml}$ ionomycin, and $10 \mu \mathrm{g} / \mathrm{ml}$ brefeldinA (Sigma, St Louis, MO, USA) at $37^{\circ} \mathrm{C}$ for $6 \mathrm{~h}$. Cells were collected, washed, and labeled with specific surface antibodies. Then, cells were washed, fixed, permeabilized, and incubated with IL-17 and IFN- $\gamma$ mAbs. Cells were performed with a FACScan flow cytometer. Cells were first gated on 510 negative cells (live cells), then gated on $\mathrm{CD}^{+} \gamma \delta \mathrm{TCR}^{+}$cells, the expression of IL-17 or IFN- $\gamma$ was analyzed (Figure 2). Data were analyzed by FlowJo software, as described above.

\section{Statistical Analysis}

Data are expressed as mean \pm SD. Statistical analysis was performed with GraphPad Prism software version 5.03 (GraphPad Software, San Diego, CA, USA). Statistical significance $P$ values for differences between groups were assessed by Mann-Whitney tests and one-way ANOVA test. The statistical dependence between variables was assessed by performing Spearman's rank correlation analysis. All tests were two-tailed, and values of $P<0.05$ were considered significant.

\section{RESULTS}

\section{Characteristics of Participants}

$26 \mathrm{AHI}, 31 \mathrm{CHI}$ patients, and $20 \mathrm{HIV}$-1-negative $\mathrm{HC}$ were enrolled in this study (Table 1). Both AHI and CHI patients were further divided into two groups $\left(\mathrm{HIV}^{+} \mathrm{RPR}^{+}\right.$or $\left.\mathrm{HIV}^{+} \mathrm{RPR}^{-}\right)$ based on the syphilis status. The information of all the subjects is presented in Table 1. The age, sex, and the nationality of the $\mathrm{HIV}$-1-infected patients and $\mathrm{HC}$ are matched. The estimated date of infection and viral load of $\mathrm{HC}$ are unavailable. The absolute number of $\mathrm{CD}^{+} \mathrm{T}$ cells and $\mathrm{CD} 4 / \mathrm{CD} 8$ ratio in $\mathrm{AHI}$ and $\mathrm{CHI}$ patients are much lower than that in $\mathrm{HC}(P<0.001)$. The absolute number of $\mathrm{CD}^{+}$and $\mathrm{CD}^{+} \mathrm{T}$ cells between HIV-1-infected patients and $\mathrm{HC}$ are not significant different $(P>0.05$, Table 1).

\section{Syphilis Infection Has Differential Effects on the Frequencies of $\gamma \delta \mathrm{T}$-Cell Subsets in Patients with AHI}

First, we investigated the effect of syphilis on the frequencies of total $\gamma \delta, \mathrm{V}_{1}$, and $\mathrm{V}_{2}$ T-cell in HIV-1-infected patients. The frequencies of total $\gamma \delta, \mathrm{V}_{1}$, and $\mathrm{V}_{2}$ T cells among three groups: $\mathrm{HC}$ $(n=20), \mathrm{HIV}^{+} \mathrm{RPR}^{-}(n=24)$, and $\mathrm{HIV}^{+} \mathrm{RPR}^{+}(n=33)$ patients were compared. As shown in Figure 3A, the frequencies of total $\gamma \delta$ T cells were not significantly different among the three groups. The frequencies of $\mathrm{V}_{1} \mathrm{~T}$ cells was significantly higher in the $\mathrm{HIV}^{+} \mathrm{RPR}^{-}$group than in $\mathrm{HC}$, but no significant difference was found compared with $\mathrm{HIV}^{+} \mathrm{RPR}^{+}$group. The frequencies of $\mathrm{V}_{2}$ T cells was significantly lower in both $\mathrm{HIV}^{+} \mathrm{RPR}^{-}$and $\mathrm{HIV}^{+} \mathrm{RPR}^{+}$ groups compared with $\mathrm{HC}$. However, we found no significant difference in $\mathrm{V}_{2}$ T-cell frequency between $\mathrm{HIV}^{+} \mathrm{RPR}^{-}$and $\mathrm{HIV}^{+} \mathrm{RPR}^{+}$groups (Figures 3B,C). Based on the above results, we assumed that $\mathrm{HIV}-1$ infection status might affect the frequencies of total $\gamma \delta, \mathrm{V}_{1}$, and $\mathrm{V}_{2}$ T cells. Therefore, we split the $\mathrm{HIV}^{+} \mathrm{RPR}^{-}$ and $\mathrm{HIV}^{+} \mathrm{RPR}^{+}$groups into subgroups of patients with $26 \mathrm{AHI}$ and $31 \mathrm{CHI}$ patients. The frequencies of total $\gamma \delta, \mathrm{V}_{1}$, and $\mathrm{V}_{2}$ $\mathrm{T}$ cells were compared between the $\mathrm{HIV}^{+} \mathrm{RPR}^{-}$and $\mathrm{HIV}^{+} \mathrm{RPR}^{+}$ subgroups with AHI and CHI. We found no significant difference of the frequencies of total $\gamma \delta$ T cells between $\mathrm{HIV}^{+} \mathrm{RPR}^{-}$and $\mathrm{HIV}^{+} \mathrm{RPR}^{+}$groups for either acute or CHI (Figure 3D). The frequencies of $\mathrm{V}_{1} \mathrm{~T}$ cells were significantly lower in the $\mathrm{HIV}^{+} \mathrm{RPR}^{+}$ group than in the $\mathrm{HIV}^{+} \mathrm{RPR}^{-}$group for $\mathrm{AHI}$ patients. By contrast, in $\mathrm{CHI}$, no significant difference of the frequencies of $\mathrm{V}_{1} \mathrm{~T}$ cells was found between the $\mathrm{HIV}^{+} \mathrm{RPR}^{+}$and $\mathrm{HIV}^{+} \mathrm{RPR}^{-}$groups. Moreover, in the $\mathrm{HIV}^{+} \mathrm{RPR}^{+}$group, the frequencies of $\mathrm{V}_{1} \mathrm{~T}$ cells were significantly higher in $\mathrm{CHI}$ patients than in AHI patients (Figure 3E). Conversely, in AHI patients, the frequencies of $\mathrm{V}_{2}$ $\mathrm{T}$ cells were significantly higher in the $\mathrm{HIV}^{+} \mathrm{RPR}^{+}$group than in the $\mathrm{HIV}^{+} \mathrm{RPR}^{-}$group. However, no significant difference of the frequencies of $\mathrm{V \delta}_{2} \mathrm{~T}$ cells between $\mathrm{HIV}^{+} \mathrm{RPR}^{-}$and $\mathrm{HIV}^{+} \mathrm{RPR}^{+}$ groups was observed in $\mathrm{CHI}$ patients. Moreover, for $\mathrm{HIV}^{+} \mathrm{RPR}^{+}$ group, the frequencies of $\mathrm{V \delta}_{2} \mathrm{~T}$ cells in AHI patients were significantly higher than that in CHI patients (Figure 3F). Taken together, these results suggest that syphilis has differential effects on the frequencies of $\mathrm{V}_{1}$ and $\mathrm{V}_{2} \mathrm{~T}$ cells in patients with HIV-1 infection, depending on that this infection is acute or chronic.

\section{Syphilis Affects $\gamma \delta \mathrm{T}$-Cell Differentiation in Patients with AHI}

Memory CD4 ${ }^{+}$T-cell depletion is a major cause of HIV-1 pathogenesis and disease progression $(35,36)$. Like $\mathrm{CD}^{+} \mathrm{T}$ cells, $\gamma \delta$ $\mathrm{T}$ cells can be split into naïve and memory T-cell subsets on the basis of their surface expression of CD45RA and CD27 (37). Herein, we found that the frequencies of naïve $\left(\mathrm{CD} 27^{+} \mathrm{CD} 45 \mathrm{RA}{ }^{+}\right.$, $\mathrm{T}_{\text {Naive }}$ ) $\gamma \delta \mathrm{T}$ cells in $\mathrm{HIV}^{+} \mathrm{RPR}^{+}$group in $\mathrm{AHI}$ patients were significantly increased compared with $\mathrm{HC}$, and $\mathrm{HIV}^{+} \mathrm{RPR}^{-}$ patients with both acute and CHI. The frequencies of $\mathrm{T}_{\text {Naive }} \gamma \delta$ $\mathrm{T}$ cells in $\mathrm{HIV}^{+} \mathrm{RPR}^{+}$group in $\mathrm{CHI}$ patients were significantly higher compared with $\mathrm{HC}$, but no significant differences were shown compared with the other 3 groups (Figure 4A). In AHI patients, the frequencies of central memory $\left(\mathrm{CD} 27^{+} \mathrm{CD} 45 \mathrm{RA}^{-}\right.$, $\left.\mathrm{T}_{\mathrm{CM}}\right) \gamma \delta \mathrm{T}$ cells in the $\mathrm{HIV}^{+} \mathrm{RPR}^{-}$group were significantly lower than that in $\mathrm{HC}$ and $\mathrm{HIV}^{+} \mathrm{RPR}^{+}$group. In CHI patients, the frequencies of $\mathrm{T}_{\mathrm{CM}} \gamma \delta \mathrm{T}$ cells were significantly higher than that in $\mathrm{HIV}^{+} \mathrm{RPR}^{-}$group in $\mathrm{AHI}$ patients (Figure 4B). Moreover, the frequencies of effector memory $\left(\mathrm{CD} 27^{-} \mathrm{CD}^{2} 5 \mathrm{RA}^{-}, \mathrm{T}_{\mathrm{EM}}\right) \gamma \delta \mathrm{T}$ cells in the $\mathrm{HIV}^{+} \mathrm{RPR}^{-}$and $\mathrm{HIV}^{+} \mathrm{RPR}^{+}$groups in both $\mathrm{AHI}$ and $\mathrm{CHI}$ patients were significantly lower than that in $\mathrm{HC}$. However, there were no significant differences of the frequencies of $\mathrm{T}_{\mathrm{EM}} \gamma \delta \mathrm{T}$ cells 

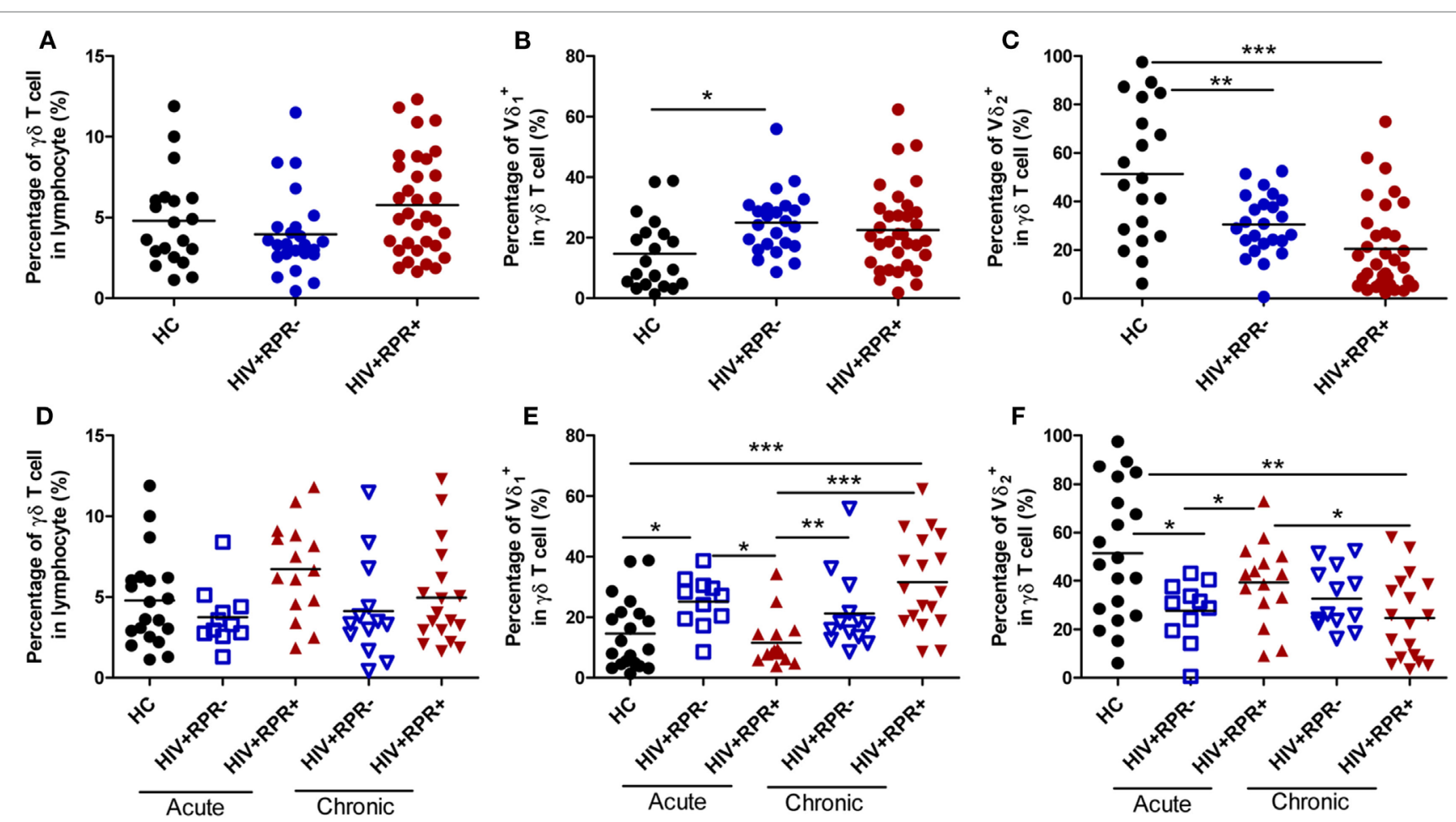

FIGURE $3 \mid$ Comparison of the frequencies of $\gamma \delta T$ cells, $V \delta_{1}$ and $V \delta_{2} T$ cells among healthy controls, HIV-1-infected and HIV-1/syphilis coinfected patients. Based on the results of rapid plasma reagin (RPR), HIV-1-infected patients were divided into $\mathrm{HIV}^{+} \mathrm{RPR}{ }^{-}$and $\mathrm{HIV}^{+} \mathrm{RPR}^{+}$groups. The percentages of $\gamma \delta \mathrm{T}$ cells $(\mathbf{A}), \mathrm{V} \delta_{1} T$ cells (B), and $\mathrm{V}_{2} T$ cells $(\mathbf{C})$ were compared among $\mathrm{HC}(\mathbf{\bullet}), \mathrm{HIV}^{+} \mathrm{RPR}^{-}(\mathbf{\bullet})$, and $\mathrm{HIV}^{+} \mathrm{RPR}^{+}(\mathbf{\bullet})$ groups. Next, $\mathrm{HIV}^{+} \mathrm{RPR}^{-}$and $\mathrm{HIV}^{+} \mathrm{RPR}^{+}$groups were subdivided according to the acute or chronic nature of their HIV-1 infection. The percentages of $\gamma \delta T$ cells $(\mathbf{D}), V \delta_{1} T$ cells $(\mathbf{E})$, and $V \delta_{2} T$ cells $(\mathbf{F})$ were compared among HIV ${ }^{+} R P R-(\square)$ and $\mathrm{HIV}^{+} \mathrm{RPR}^{+}(\mathbf{\Delta})$ groups in acute HIV-1 infection and $\mathrm{HIV}^{+} \mathrm{RPR}^{-}(\nabla)$ and $\mathrm{HIV}^{+} \mathrm{RPR}^{+}(\boldsymbol{\nabla})$ groups in chronic HIV-1 infection. The significance of differences was determined by calculating $P$ values in Mann-Whitney tests and one-way ANOVA test. ${ }^{\star} P<0.05,{ }^{\star \star} P<0.01,{ }^{\star \star \star} P<0.001$. HC, healthy controls; HIV+RPR ${ }^{+}$, patients coinfected with HIV-1 and syphilis; HIV+RPR-, patients infected with HIV-1 without syphilis.

between the $\mathrm{HIV}^{+} \mathrm{RPR}^{-}$and $\mathrm{HIV}^{+} \mathrm{RPR}^{+}$groups in both $\mathrm{AHI}$ and $\mathrm{CHI}$ patients (Figure 4C). Finally, we found the frequencies of terminally differentiated $\left(\mathrm{CD} 27^{-} \mathrm{CD} 45 \mathrm{RA}^{+}, \mathrm{T}_{\mathrm{EMRA}}\right) \gamma \delta \mathrm{T}$ cells in $\mathrm{HIV}^{+} \mathrm{RPR}^{-}$group in $\mathrm{AHI}$ patients were significantly higher than that in $\mathrm{HC}$ and $\mathrm{HIV}^{+} \mathrm{RPR}^{+}$groups in both $\mathrm{AHI}$ and $\mathrm{CHI}$ patients. There was no significant difference between the $\mathrm{HIV}^{+} \mathrm{RPR}^{-}$and $\mathrm{HIV}^{+} \mathrm{RPR}^{+}$groups in CHI patients (Figure $4 \mathrm{D}$ ).

Different $\gamma \delta$ T-cell subsets exhibit different effector functions. $\mathrm{CD} 27^{-} \mathrm{V} \gamma_{9} \mathrm{~V} \delta_{2} \mathrm{~T}$ cells are considered as the major producer of IL-17 $(38,39)$ and neutrophils can regulate IL-17 production by $\gamma \delta \mathrm{T}$ cells $(40-42)$. Therefore, we analyzed the relationships between the frequencies of $\mathrm{T}_{\text {Naive }}, \mathrm{T}_{\mathrm{CM}}, \mathrm{T}_{\mathrm{EM}}$, and $\mathrm{T}_{\mathrm{EMRA}} \gamma \delta \mathrm{T}$ cells and the frequencies of neutrophils (Figure S1 in Supplementary Material). We found that the frequencies of $T_{E M} \gamma \delta \mathrm{T}$ cells were positively correlated with the frequencies of neutrophils. However, no relationships were observed between the frequencies of $\mathrm{T}_{\text {Naive, }}, \mathrm{T}_{\mathrm{CM}}$, and $\mathrm{T}_{\mathrm{EMRA}} \gamma \delta \mathrm{T}$ cells and the frequencies of neutrophils (Figure S1 in Supplementary Material).

\section{Syphilis Coinfection Effects on $\gamma \delta$ T-Cell Activation following Different Stages of HIV-1 Infection}

We have shown that $\gamma \delta \mathrm{T}$ cells were over-activated in HIV1-infected patients, and associated with disease progression
$(26,43)$. Here, we investigated the effects of syphilis on $\gamma \delta$ T-cell activation by comparing $\gamma \delta$ T-cell activation among HC, the $\mathrm{HIV}^{+} \mathrm{RPR}^{+}$and $\mathrm{HIV}^{+} \mathrm{RPR}^{-}$groups in both $\mathrm{AHI}$ and $\mathrm{CHI}$ patients. Consistent with our previous results, we found that the frequencies of $\mathrm{CD}^{2} 8^{+} \gamma \delta \mathrm{T}$ cells were significantly higher in both the $\mathrm{HIV}^{+} \mathrm{RPR}^{+}$and $\mathrm{HIV}^{+} \mathrm{RPR}^{-}$groups in $\mathrm{AHI}$ and $\mathrm{CHI}$ patients, compared with HC. In AHI patients, the frequencies of $\mathrm{CD} 38^{+} \gamma \delta$ $\mathrm{T}$ cells in $\mathrm{HIV}^{+} \mathrm{RPR}^{+}$group were significantly lower than that in $\mathrm{HIV}^{+} \mathrm{RPR}^{-}$group (Figure 5A). In addition, we found that, in AHI patients, the frequencies of HLA-DR ${ }^{+} \delta \delta$ T cells and CD $38^{+} \mathrm{HLA}-$ $\mathrm{DR}^{+} \gamma \delta \mathrm{T}$ cells were significantly lower in the $\mathrm{HIV}^{+} \mathrm{RPR}^{+}$group than in the $\mathrm{HIV}^{+} \mathrm{RPR}^{-}$group (Figures 5B,C). By contrast, in CHI patients, the frequencies of HLA-DR ${ }^{+} \gamma \delta \mathrm{T}$ cells and $\mathrm{CD} 38^{+} \mathrm{HLA}-$ $\mathrm{DR}^{+} \gamma \delta \mathrm{T}$ cells were significantly higher in the $\mathrm{HIV}^{+} \mathrm{RPR}^{+}$group than that in the $\mathrm{HIV}^{+} \mathrm{RPR}^{-}$group (Figures $5 \mathrm{~B}, \mathrm{C}$ ). Moreover, the frequencies of $\mathrm{CD} 38^{+}$, HLA-DR ${ }^{+}$, and $\mathrm{CD} 38^{+} \mathrm{HLA}-\mathrm{DR}^{+} \gamma \delta$ T cells in CHI patients, both $\mathrm{HIV}^{+} \mathrm{RPR}^{+}$and $\mathrm{HIV}^{+} \mathrm{RPR}^{-}$groups, were significantly higher than that in $\mathrm{HIV}^{+} \mathrm{RPR}^{+}$group in AHI patients (Figures 5A-C). In a previous study, it was reported that neutrophils inhibited $\gamma \delta$ T-cell activation (44), we therefore analyzed the relationship between $\gamma \delta$ T-cell activation and the percentage of neutrophils. We found that there were no correlations between the frequencies of $\mathrm{CD} 38^{+}$, HLA-DR ${ }^{+}$, and CD $38^{+}$HLA-DR ${ }^{+} \gamma \delta$ T cells and the percentages of neutrophils 

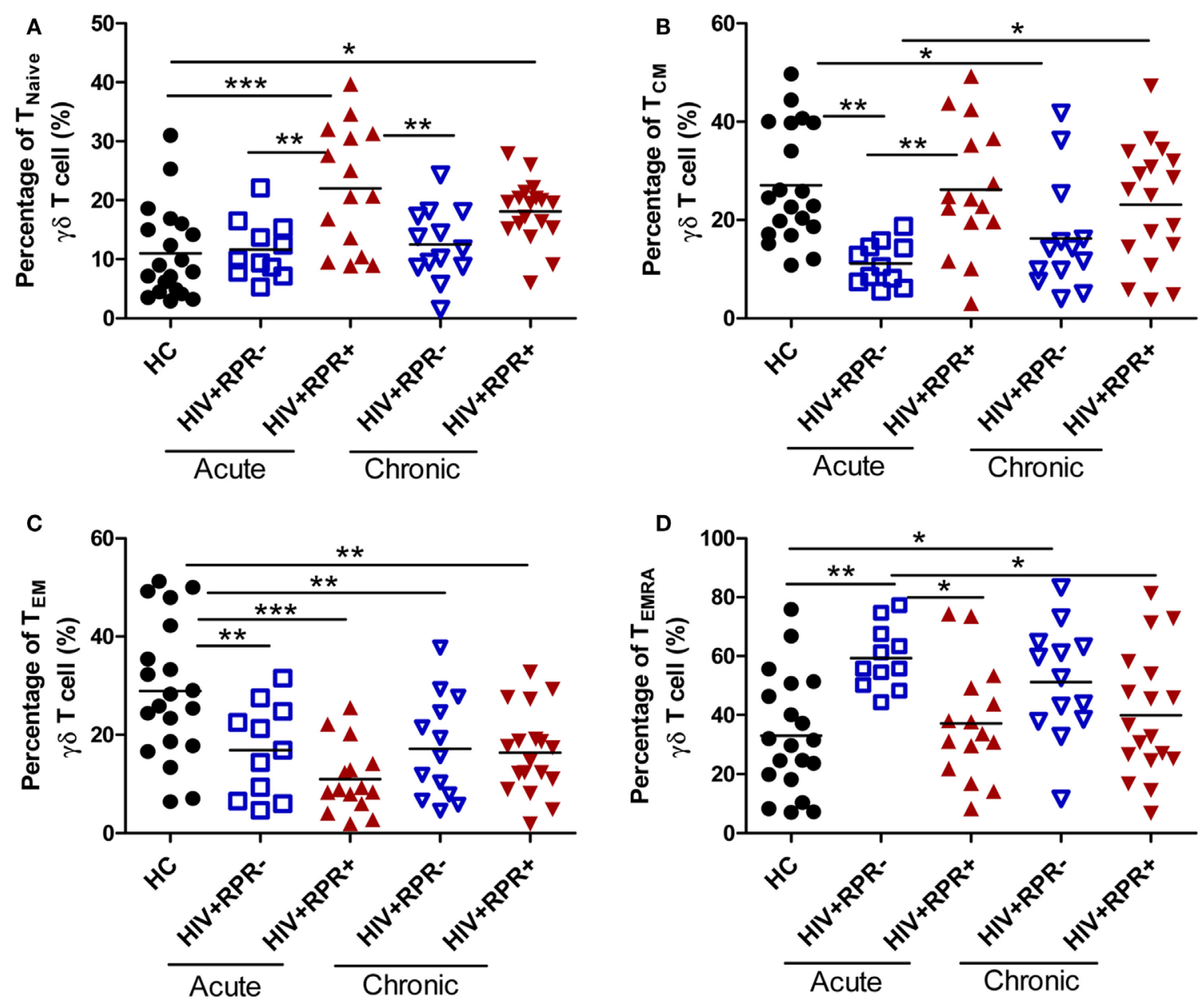

FIGURE 4 | Syphilis coinfection has effects on the functional subsets of $\gamma \delta$ T cells in HIV-1-infected patients. $\gamma \delta \mathrm{T}$ cells were classified into four different functional subsets according to their CD27 and CD45RA expression. The percentages of $T_{\text {Naive }} \gamma \delta T_{\text {cells (A), } T_{\text {CM }} \gamma \delta} \delta$ cells (B), TEM $\gamma \delta T$ cells (C), and TEMRA $\gamma \delta T$ cells (D) were compared among HC, $\mathrm{HIV}^{+} \mathrm{RPR}^{-}(\square)$, and $\mathrm{HIV}^{+} \mathrm{RPR}^{+}(\mathbf{\Delta})$ groups in acute $\mathrm{HIV}-1$-infected patients and $\mathrm{HIV}^{+} \mathrm{RPR}^{-}(\nabla)$ and $\mathrm{HIV}^{+} \mathrm{RPR} \mathrm{R}^{+}(\boldsymbol{\nabla})$ groups in chronic HIV-1-infected patients. The significance of differences was assessed by calculating $P$ values in Mann-Whitney tests. ${ }^{\star} P<0.05$, ${ }^{\star \star} P<0.01,{ }^{\star \star \star} P<0.001$. RPR, rapid plasma reagin.

(Figure S2 in Supplementary Material). Thus, HIV-1 infection appears to lead to $\gamma \delta \mathrm{T}$-cell over-activation. However, syphilis can differentially affect $\gamma \delta$ T-cell activation status, depending on the acute or chronic nature of the HIV-1 infection.

\section{IL-17-Producing $\gamma \delta \mathrm{T}$ Cells Are Positively Correlated with the Percentage of Neutrophils in HIV-1-Infected Patients}

Previous studies have shown that IL-17 levels in the peripheral blood or central nervous system (CFS) increase in patients with asymptomatic neurosyphilis and secondary syphilis, possibly as part of the immune response to T. palladium infection $(19,20,27,45) . \gamma \delta \mathrm{T}$ cells are a major source of IL-17, which is involved in inflammation and immune response $(46,47)$. Therefore, we assessed and compared the frequencies of IL-17producing and IFN- $\gamma$-producing $\gamma \delta \mathrm{T}$ cells in $\mathrm{HC}$, and in the $\mathrm{HIV}^{+} \mathrm{RPR}^{+}$and $\mathrm{HIV}^{+} \mathrm{RPR}^{-}$patients with acute and $\mathrm{CHI}$. We found that the frequencies of IL-17-producing $\gamma \delta \mathrm{T}$ cells were significantly higher in $\mathrm{CHI}$ patients than in $\mathrm{HC}$, particularly for the $\mathrm{HIV}^{+} \mathrm{RPR}^{+}$group (Figure 6A). Surprisingly, we found a significant difference in the frequencies of IL-17-producing $\gamma \delta \mathrm{T}$ cells between the $\mathrm{HIV}^{+} \mathrm{RPR}^{+}$and $\mathrm{HIV}^{+} \mathrm{RPR}^{-}$groups was observed in $\mathrm{CHI}$ patients, but not in AHI patients. Moreover, the frequencies of IL-17-producing $\gamma \delta \mathrm{T}$ cells in $\mathrm{HIV}^{+} \mathrm{RPR}^{+}$ group in $\mathrm{CHI}$ patients were significantly higher than that in both $\mathrm{HIV}^{+} \mathrm{RPR}^{+}$and $\mathrm{HIV}^{+} \mathrm{RPR}^{-}$groups in $\mathrm{AHI}$ patients (Figure 6A). In addition, the frequency of IFN- $\gamma$-producing $\gamma \delta \mathrm{T}$ cells was significantly lower in the $\mathrm{HIV}^{+} \mathrm{RPR}^{+}$group in $\mathrm{CHI}$ patients than that in HC. The frequencies of IFN- $\gamma$-producing $\gamma \delta \mathrm{T}$ cells in $\mathrm{HIV}^{+} \mathrm{RPR}^{+}$group in $\mathrm{AHI}$ patients were significantly higher than that in $\mathrm{HIV}^{+} \mathrm{RPR}^{+}$group in $\mathrm{CHI}$ patients. However, there was no significant difference in the frequency of IFN- $\gamma$-producing $\gamma \delta \mathrm{T}$ cells between the $\mathrm{HIV}^{+} \mathrm{RPR}^{+}$and $\mathrm{HIV}^{+} \mathrm{RPR}^{-}$groups in both AHI and CHI patients (Figure 6B). Thus, both IL-17 and IFN- $\gamma$ may be involved in $\gamma \delta$ T-cell-mediated immune 

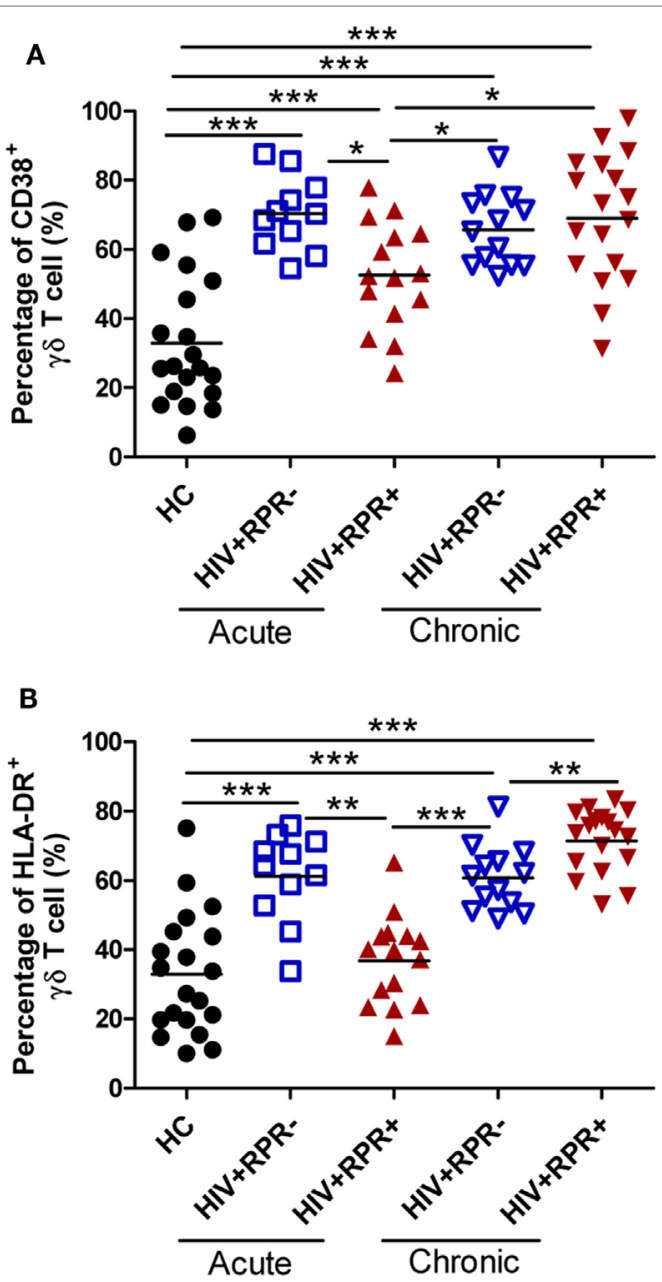

C

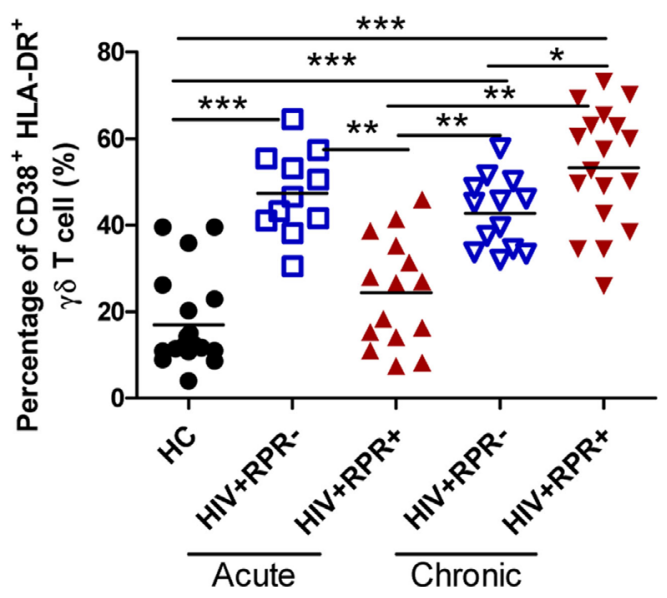

FIGURE 5 | Syphilis coinfection affects differently $\gamma \delta$ T-cell activation in patients with acute and chronic HIV-1 infection. $\gamma \delta$ T-cell activation was assessed by evaluating the expression of CD38 and HLA-DR. The frequencies of $\mathrm{CD}^{2} 8^{+} \gamma \delta \mathrm{T}$ cells (A), $\mathrm{HLA}^{-D R^{+}} \gamma \delta \mathrm{T}$ cells (B), and CD38+HLA$\mathrm{DR}^{+} \gamma \delta \mathrm{T}$ cells (C) were compared among $\mathrm{HC}, \mathrm{HIV}^{+} \mathrm{RPR}^{-}(\square)$, and $\mathrm{HIV}^{+} \mathrm{RPR}^{+}$ (A) groups in acute HIV-1-infected patients and $\mathrm{HIV}^{+} \mathrm{RPR}^{-}(\nabla)$ and $\mathrm{HIV}^{+} \mathrm{RPR}^{+}(\boldsymbol{\nabla})$ groups in chronic HIV-1-infected patients. The significance of differences was determined by calculating $P$ values in Mann-Whitney tests. ${ }^{\star} P<0.05,{ }^{\star \star} P<0.01,{ }^{\star \star \star} P<0.001$. RPR, rapid plasma reagin. response to syphilis, which seems to depend on HIV-1 disease stage. Recent studies have shown that neutrophils can suppress $\gamma \delta$ T-cell activation, proliferation, and IFN- $\gamma$ production (44, 48). However, Coffelt et al. reported that neutrophils promoted IL-17 production by $\gamma \delta \mathrm{T}$ cells, leading to tumor metastasis (49). We therefore hypothesized that the differences in $\gamma \delta$ T-cell functions in $\mathrm{AHI}$ and $\mathrm{CHI}$ patients might be associated with neutrophils. We analyzed the relationships between IL-17- or IFN- $\gamma$-producing $\gamma \delta$ T cells and the percentage of neutrophils. We found that the frequencies of IL-17-producing $\gamma \delta \mathrm{T}$ cells were positively correlated with the percentage of neutrophils (Figure 6C). However, no correlation was found between the frequencies of IFN- $\gamma$-producing $\gamma \delta \mathrm{T}$ cells and the percentage of neutrophils (Figure 6D). Taken together, these results suggest that syphilis may lead to the recruitment of neutrophils to local sites, where they promote the production of IL-17 by $\gamma \delta \mathrm{T}$ cells, leading to inflammation, immune activation, and an acceleration of HIV-1 disease progression.

\section{DISCUSSION}

HIV-1 and syphilis, two sexually transmitted diseases, show rapidly increasing incidences of coinfection in MSM population $(2,11) . \gamma \delta \mathrm{T}$ cells, a critical component of the host immune system, play an important role in controlling HIV-1 infection. However, the effects of syphilis on $\gamma \delta$ T-cell phenotype and function remain unclear. Herein, we examined and compared the phenotype and function of $\gamma \delta \mathrm{T}$ cells in the $\mathrm{HIV}^{+} \mathrm{RPR}^{+}$and $\mathrm{HIV}^{+} \mathrm{RPR}^{-}$groups of patients with $\mathrm{AHI}$ and $\mathrm{CHI}$ separately. Consistent with previous studies $(26,50)$, we found that HIV-1 infection disrupted the balance of $\mathrm{V}_{1}$ and $\mathrm{V} \delta_{2} \mathrm{~T}$ cells, increased the frequency of $\mathrm{V}_{1} \mathrm{~T}$ cells, and decreased the frequency of $\mathrm{V}_{2} \mathrm{~T}$ cells (Figures $3 \mathbf{B}, \mathrm{C}$ ). Interestingly, we found that syphilis corrected the imbalance of $\mathrm{V}_{1}$ and $\mathrm{V}_{2} \mathrm{~T}$ cells in patients with AHI, by decreasing the proportion of $\mathrm{V}_{1} \mathrm{~T}$ cells and increasing that of $\mathrm{V}_{2} \mathrm{~T}$ cells (Figures 3E,F). However, this effect was not observed in patients with $\mathrm{CHI}$. The mechanisms by which syphilis affects the proportions of $\mathrm{V}_{1}$ and $\mathrm{V}_{2} \mathrm{~T}$ cells in patients with $\mathrm{AHI}$ are unknown, but may involve an induction of $\mathrm{V} \delta_{1}$ T-cell proliferation by $T$. pallidum antigens early in infection (51). In this study, we found that syphilis coinfection among HIV-1-infected patients did not affect the frequency of total $\gamma \delta$ $\mathrm{T}$ cells; this may due to the mutual compensation of $V \delta_{1}$ and $\mathrm{V}_{2} \mathrm{~T}$ cells. The frequencies of $\mathrm{V}_{2} \mathrm{~T}$ cells in healthy controls are diffusion, which appeared to be donor dependent. $V \delta_{1}$ and $\mathrm{V}_{2} \mathrm{~T}$ cells exhibit different features in location site, cytokine secretion, and cytotoxicity $(24,46,52,53)$. Therefore, it would be more helpful to understand the mechanisms of how syphilis differentially regulates the phenotype and function of $\gamma \delta \mathrm{T}$ cells by analyzing the phenotypes and functions of $\mathrm{V}_{1}$ and $\mathrm{V}_{2} \mathrm{~T}$ cells separately in the further studies.

$\gamma \delta \mathrm{T}$ cells can be classified into $\mathrm{T}_{\text {Naive }}, \mathrm{T}_{\mathrm{CM}}, \mathrm{T}_{\mathrm{EM}}$, and $\mathrm{T}_{\mathrm{EMRA}}$ four functional subsets. $\mathrm{T}_{\text {Naive }}$ and $\mathrm{T}_{\mathrm{CM}} \gamma \delta \mathrm{T}$ cells are located in lymph nodes and short of immediate effector function, whereras $\mathrm{T}_{\mathrm{EM}}$ and $\mathrm{T}_{\mathrm{EMRA}} \gamma \delta \mathrm{T}$ cells prefer to locate in inflammatory sites and show immediate effector functions (54). We found that the frequencies of $\mathrm{T}_{\text {Naive }}$ and $\mathrm{T}_{\mathrm{CM}} \gamma \delta \mathrm{T}$ cells were significantly higher, 

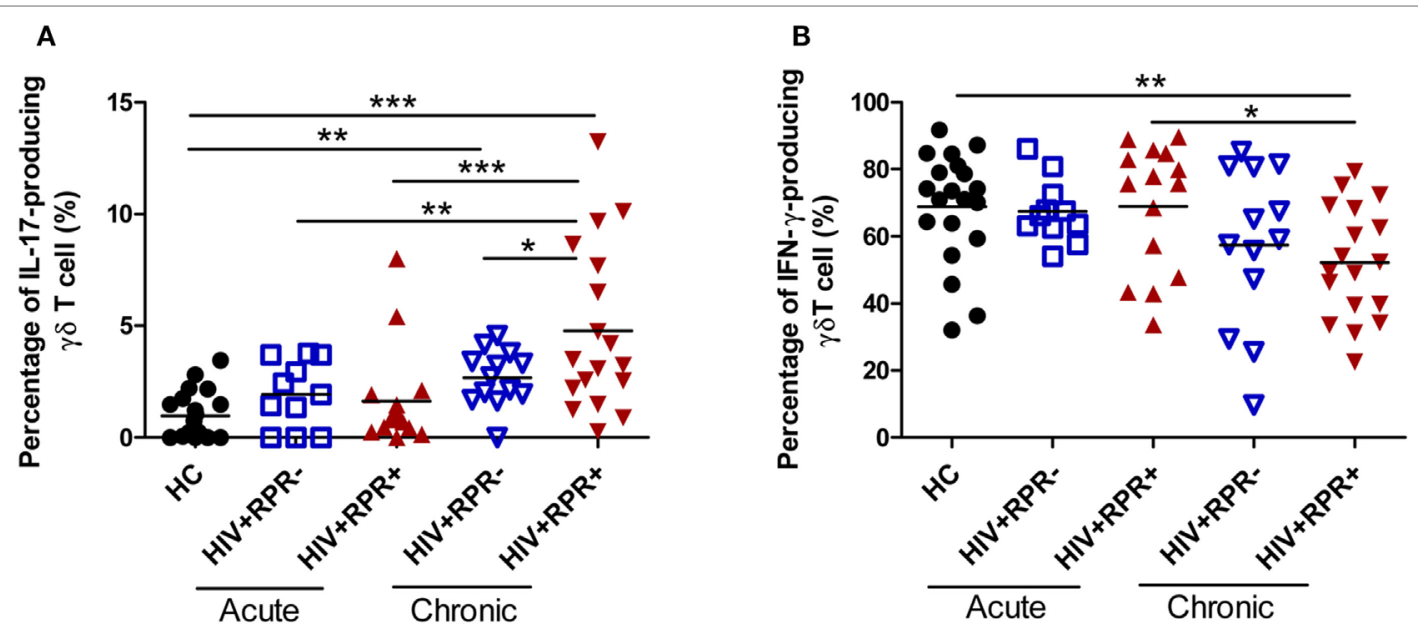

C

D
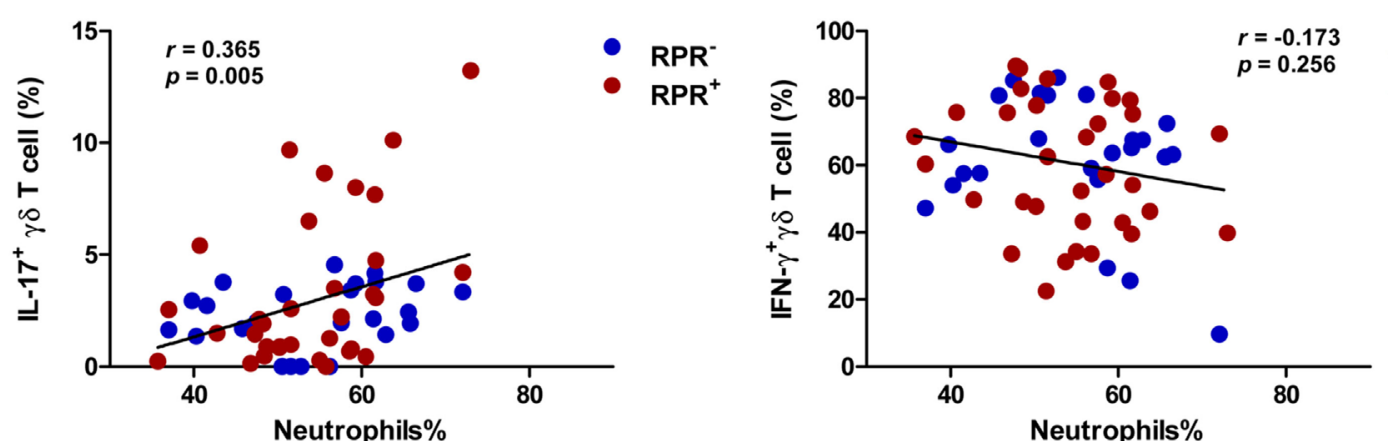

FIGURE 6 | Syphilis coinfection promotes the production of IL-17 by $\gamma \delta$ T cells in patients with chronic HIV- 1 infection. Peripheral blood mononuclear cells $\left(1 \times 10^{6} \mathrm{cells} / \mathrm{ml}\right)$ were used to seed 24-well plates, and they were incubated with PMA $(50 \mathrm{ng} / \mathrm{ml}) /$ ionomycin $(1 \mathrm{\mu g} / \mathrm{ml})$ for $6 \mathrm{~h}$ and BFA $(10 \mu \mathrm{g} / \mathrm{ml})$ was added $2 \mathrm{~h}$ before cell harvests. Intracellular staining for IL-17 and IFN- $\gamma$ was assessed by flow cytometry. Comparisons of the frequencies of IL-17-producing $\gamma \delta$ T cells (A) and IFN- $\gamma$-producing $\gamma \delta$ T cells (B) among HIV+RPR- $(\square)$ and $\mathrm{HIV}^{+} \mathrm{RPR}^{+}(\mathbf{\Lambda})$ groups in acute HIV-1-infected patients and $\mathrm{HIV}^{+} \mathrm{RPR}-(\nabla)$ and $\mathrm{HIV}^{+} \mathrm{RPR}^{+}(\boldsymbol{\nabla})$ groups in chronic HIV-1-infected patients. Correlations of the proportions of IL-17-producing $\gamma \delta$ T cells (C) and IFN- $\gamma$-producing $\gamma \delta$ T cells (D) with the percentage of neutrophils in $\mathrm{HIV}^{+} \mathrm{RPR}^{+}(\mathbf{\bullet})$ and $\mathrm{HIV}^{+} \mathrm{RPR}^{-}(\mathbf{\bullet})$ groups were analyzed. The significance of differences was assessed by calculating $P$ values in Mann-Whitney tests. Spearman's rank correlation analysis was used to assess correlations. ${ }^{\star} P<0.05,{ }^{\star \star} P<0.01,{ }^{\star \star \star} P<0.001$. RPR, rapid plasma reagin.

but the frequencies of $\mathrm{T}_{\mathrm{EM}}$ and $\mathrm{T}_{\mathrm{EMRA}} \gamma \delta \mathrm{T}$ cells were significantly lower in $\mathrm{HIV}^{+} \mathrm{RPR}^{+}$group than those in $\mathrm{HIV}^{+} \mathrm{RPR}^{-}$group in patients with acute HIV-1-infected patients (Figure 4). These results suggest that T. pallidum may trigger $\gamma \delta$ T-cell proliferation and differentiation, in a manner dependent on the HIV-1 stage in coinfected patients, and that the changes of the frequencies of $\mathrm{T}_{\text {Naive }}, \mathrm{T}_{\mathrm{CM}}, \mathrm{T}_{\mathrm{EM}}$, and $\mathrm{T}_{\mathrm{EMRA}} \gamma \delta \mathrm{T}$ cells may be associated with $\gamma \delta$ T-cell activation (26). Furthermore, we observed a positive correlation between the frequencies of $\mathrm{T}_{\mathrm{EM}} \gamma \delta \mathrm{T}$ cells and the percentage of neutrophils in AHI. This may indicate that mutual interactions between immune cells may also have some effects on $\gamma \delta$ T-cell differentiation.

Chronic immune activation is a key hallmark of HIV-1 infection and pathogenesis (55). We found here that $\gamma \delta \mathrm{T}$ cells are activated in all patients with both $\mathrm{AHI}$ and $\mathrm{CHI}$, regardless of syphilis (Figure 5). However, syphilis infection regulates $\gamma \delta$ T-cell activation status following the different stage of HIV-1

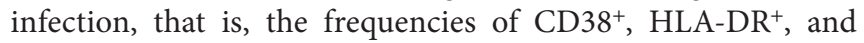
$\mathrm{CD}_{3} 8^{+} \mathrm{HLA}-\mathrm{DR}^{+} \gamma \delta \mathrm{T}$ cells were decreased in patients with $\mathrm{AHI}$ but they were increased in patients with CHI (Figure 5).
These differential effects may be mediated by the spirochetal lipoproteins, abundant membrane proteins inducing a strong immune response. Moreover, these lipoproteins, which enable the spirochetes to adhere to the host, determine the interaction between the spirochetes and the host environment and immune system (56). It has been suggested that spirochetal membrane lipoproteins bear pathogen-associated molecular patterns that bind to pattern recognition receptors such as Toll-like receptors (TLRs). Spirochetal lipoproteins (T. pallidum lipoproteins) are therefore pro-inflammatory. They may activate monocytes by binding to CD14, or macrophages through a TLR-dependent pathway, leading to the production of pro-inflammatory cytokines (57-60), which drive inflammation and induce $\gamma \delta$ T-cell activation in patients with syphilis. The fact that syphilis differentially modulates $\gamma \delta$ T-cell activation may be ascribed to the different host immune environments exhibited in patients with AHI and CHI. Moreover, interactions among immune cells may affect $\gamma \delta$ T-cell activation (61). However, we did not observe any correlation between $\gamma \delta$ T-cell activation and neutrophils in AHI. The precise mechanisms by which syphilis differentially 
modulates $\gamma \delta$ T-cell activation are not fully understood and deserve further investigation.

IL-17, an inflammatory cytokine, has two principal effects: host protection and immunopathogenesis, with high levels leading to cancer progression and autoimmune diseases (62). Plasma IL-17 concentration increases in secondary syphilis, possibly as part of the immune response $(20,45)$. Syphilis also affects the liver, where it may cause syphilitic hepatitis or hepatic inflammatory tumors in HIV-1-positive MSM (63). However, the role of IL-17 and IL-17-producing $\gamma \delta \mathrm{T}$ cells in HIV-1infected patients with syphilis remains unclear. In this study, we found that patients with CHI, particularly for the $\mathrm{HIV}^{+} \mathrm{RPR}^{+}$ group have an increase in the proportion of IL-17-producing $\gamma \delta \mathrm{T}$ cells, which was positively correlated with the percentage of neutrophils (Figures 6A,C). Our findings suggest that the immune response to $T$. pallidum promotes the production of IL-17 by $\gamma \delta$ T cells in patients with $\mathrm{CHI}$, leading to the recruitment of neutrophils to the inflammatory site, and to mediate the immune response $(44,63,64)$. We previously showed that the frequency of IL-17-producing $\gamma \delta \mathrm{T}$ cells was correlated with $\gamma \delta$ T-cell activation (26). We also show here that change of activated $\gamma \delta$ T cells has a similar trend with the frequency of IL-17-producing $\gamma \delta$ T cells in all patients (Figures 5 and 6). Together, these findings suggest that syphilis induces the production of IL-17 by $\gamma \delta \mathrm{T}$ cells, thereby promoting neutrophilmediated immunity, triggering $\gamma \delta$ T-cell immune activation, and accelerating HIV-1 disease progression. Neutrophils have recently been recognized as a source of IL-17 (40). However, the effects of neutrophils on $\gamma \delta$ T cells remain unclear. Further studies on the $\gamma \delta \mathrm{T}$-cell/IL-17/neutrophil axis are therefore required to elucidate the mechanisms of $\gamma \delta$ T-cell action in HIV-1 pathogenesis and HIV-1 disease progression.

In summary, syphilis infection decreases immune activation and the secretion of inflammatory cytokines in AHI. To our knowledge, it's the first time to reveal the role of $\gamma \delta$ T cells in HIV-1 and syphilis coinfection. However, it remains unclear why and how syphilis differentially regulates the $\gamma \delta \mathrm{T}$-cell immune response at different stages of HIV-1 infection. The different effects of syphilis on $\gamma \delta$ T cells may relate to the different host immune environments in $\mathrm{AHI}$ and $\mathrm{CHI}$ and the natural features of $\gamma \delta \mathrm{T}$ cells which respond in the early stages of infection. Moreover, younger age other than $\mathrm{CD} 4^{+} \mathrm{T}$-cell, nadir $\mathrm{CD} 4^{+}$ $\mathrm{T}$-cell, or $\mathrm{CD}^{+} \mathrm{T}$-cell counts may be one of the key factors that affect the phenotype and function of $\gamma \delta$ T cells (65). Therefore, syphilis should be followed up, monitored, and treated in the MSM population and in patients with AHI. In addition, there are still some limitations in this study. First, the sample size is small that may cause experimental deviation; second, we did not take into consideration other pathogens in this study, such as human cytomegalovirus and Candida albicans infection, which also have some effects on $\gamma \delta$ T cells (66-69), although the medians of CD4 T-cell count among HIV-1-infected patients more than 400 cells/ $\mu$ l (Table 1). Therefore, larger samples and more detailed studies in further investigation are required to address these issues in depth. Our observations provide new insight into the roles of $\gamma \delta \mathrm{T}$ cells in immunopathogenesis of syphilis and HIV coinfection, particularly during AHI. Our findings may be helpful for the prevention of syphilis and other sexually transmitted infections, which is just the dedication in this research and highlights the great significance on the remedy of patients coinfected with HIV.

\section{ETHICS STATEMENT}

This study and all relevant experiments have been approved by the Beijing You'an Hospital Research Ethics Committee and written informed consent was obtained from each participant according to the declaration of Helsinki. All the participants provided written informed consent for their information, and clinical samples were stored and used for research. At enrollment, all subjects provided baseline demographic, clinical and epidemiological information by completing a standardized questionnaire. The methods were carried out in accordance with approved guidelines and regulations.

\section{ACKNOWLEDGMENTS}

We thank Wei Xia, Yuefang Zhou for patients recruiting, blood and information collecting; Yunxia Ji and Rui Wang for cell counting and viral load detecting, and the individuals participated in our study, for their interest and commitment to the project, which made this work possible.

\section{AUTHOR CONTRIBUTIONS}

ZL, HW, BS, and TZ conceived and designed the experiments; QZ, AS, YG, JY, and XH collected the sample information, contributed to reagents and materials; $\mathrm{ZL}, \mathrm{XL}, \mathrm{ZH}, \mathrm{ZWL}, \mathrm{AS}$ and DM performed the experiments and analyzed the data; and ZL, BS, WJ, HW, and TZ wrote the manuscript. All authors read and approved the final manuscript.

\section{FUNDING}

This work was supported by the National Natural Science Foundation of China (81501731, 81501732, 81571973), the Beijing Municipal of Science and Technology Major Project (D141100000314005, D141100000314002, D161100000416003), the Funding for Chinese overseas talents returning to China in 2016 (BS), the Basic-Clinical Research Cooperation Fund of Capital Medical University (17JL20), the Beijing Key Laboratory for HIV/AIDS Research (BZ0089), the NSFC-NIH Biomedical collaborative research program (81761128001), and the National Institutes of Health grants (R01 AI091526, AI128864 to WJ).

\section{SUPPLEMENTARY MATERIAL}

The Supplementary Material for this article can be found online at http://journal.frontiersin.org/article/10.3389/fimmu.2017.00991/ full\#supplementary-material. 
FIGURE S1 | Correlations between the frequencies of $T_{\text {Nave }}, T_{C M}, T_{\text {EM }}$, and $T_{\text {EMRA }} \gamma \delta$ $T$ cells and neutrophils. $\gamma \delta T$ cells can be divided into four functional subsets according to the expression of CD27 and CD45RA. There were no correlations between the frequencies of $T_{\text {Nave }}$ (A), $T_{C M}$ (B), $T_{E M}$ (C), and $T_{\text {EMPA }}$ (D) $\gamma \delta$ T cells and the percentage of neutrophils in all HIV-1-infected patients with RPR- and RPR ${ }^{+}$. The frequencies of $T_{\text {ЕM }} \gamma \delta T$ cells were positively correlated with the percentage of neutrophils in acute and all HIV-1-infected patients with $\operatorname{RPR}^{-}(\mathbf{\bullet})$ and $\operatorname{RPR}^{+}(\mathbf{(})$. Correlations were calculated by using Spearman's rank correlation. $P<0.05$ was considered to be statistically significant. RPR, rapid plasma reagin.

\section{REFERENCES}

1. Jansen K, Schmidt AJ, Drewes J, Bremer V, Marcus U. Increased incidence of syphilis in men who have sex with men and risk management strategies, Germany, 2015. Euro Surveill (2016) 21:30382. doi:10.2807/1560-7917.ES. 2016.21.43.30382

2. Ahn JY, Boettiger D, Kiertiburanakul S, Merati TP, Huy BV, Wong WW, et al. Incidence of syphilis seroconversion among HIV-infected persons in Asia: results from the TREAT Asia HIV observational database. J Int AIDS Soc (2016) 19:20965. doi:10.7448/IAS.19.1.20965

3. Liu G, Lu H, Wang J, Xia D, Sun Y, Mi G, et al. Incidence of HIV and syphilis among men who have sex with men (MSM) in Beijing: an open cohort study. PLoS One (2015) 10:e0138232. doi:10.1371/journal.pone.0138232

4. Chen YC, Liu HY, Li CY, Lee NY, Li CW, Ko WC, et al. The rising trend of sexually transmitted infections among HIV-infected persons: a population-based cohort study in Taiwan, 2000 through 2010. J Acquir Immune Defic Syndr (2015) 68:432-8. doi:10.1097/QAI.0000000000000477

5. Burchell AN, Allen VG, Gardner SL, Moravan V, Tan DH, Grewal R, et al. High incidence of diagnosis with syphilis co-infection among men who have sex with men in an HIV cohort in Ontario, Canada. BMC Infect Dis (2015) 15:356. doi:10.1186/s12879-015-1098-2

6. Mao H, Ma W, Lu H, Wang L, Zheng H, Zhu Y, et al. High incidence of HIV and syphilis among migrant men who have sex with men in Beijing, China: a prospective cohort study. BMJ Open (2014) 4:e005351. doi:10.1136/ bmjopen-2014-005351

7. Syphilis on the rise in the USA. Lancet (2011) 378:542. doi:10.1016/S01406736(11)61274-9

8. Kotsafti O, Paparizos V, Kourkounti S, Chatziioannou A, Nicolaidou E, Kapsimali V, et al. Early syphilis affects markers of HIV infection. Int J STD AIDS (2016) 27:739-45. doi:10.1177/0956462415592326

9. Kofoed K, Gerstoft J, Mathiesen LR, Benfield T. Syphilis and human immunodeficiency virus (HIV)-1 coinfection: influence on CD4 T-cell count, HIV-1 viral load, and treatment response. Sex Transm Dis (2006) 33:143-8. doi:10.1097/01.olq.0000187262.56820.c0

10. Buchacz K, Patel P, Taylor M, Kerndt PR, Byers RH, Holmberg SD, et al. Syphilis increases HIV viral load and decreases CD4 cell counts in HIVinfected patients with new syphilis infections. AIDS (2004) 18:2075-9. doi:10.1097/00002030-200410210-00012

11. Roberts CP, Klausner JD. Global challenges in human immunodeficiency virus and syphilis coinfection among men who have sex with men. Expert Rev Anti Infect Ther (2016) 14:1037-46. doi:10.1080/14787210.2016.1236683

12. Pialoux G, Vimont S, Moulignier A, Buteux M, Abraham B, Bonnard P. Effect of HIV infection on the course of syphilis. AIDS Rev (2008) 10:85-92.

13. Lynn WA, Lightman S. Syphilis and HIV: a dangerous combination. Lancet Infect Dis (2004) 4:456-66. doi:10.1016/S1473-3099(04)01061-8

14. Colomer-Lluch M, Gollahon LS, Serra-Moreno R. Anti-HIV factors: targeting each step of HIV's replication cycle. Curr HIV Res (2016) 14:175-82. doi:10.2 174/1570162X14999160224094621

15. Simon V, Bloch N, Landau NR. Intrinsic host restrictions to HIV-1 and mechanisms of viral escape. Nat Immunol (2015) 16:546-53. doi:10.1038/ ni.3156

16. Vanpouille C, Introini A, Morris SR, Margolis L, Daar ES, Dube MP, et al. Distinct cytokine/chemokine network in semen and blood characterize different stages of HIV infection. AIDS (2016) 30:193-201. doi:10.1097/ QAD.0000000000000964

17. Santa-Marta M, de Brito PM, Godinho-Santos A, Goncalves J. Host factors and HIV-1 replication: clinical evidence and potential therapeutic approaches. Front Immunol (2013) 4:343. doi:10.3389/fimmu.2013.00343
FIGURE S2 | Correlation between $\gamma \delta$ T-cell activation and neutrophils. Two immune activation markers CD38 and HLA-DR were used to evaluate and compare $\gamma \delta$ T-cell activation status in both $\mathrm{HC}$ and HIV-1-infected patients with $\mathrm{RPR}^{-}$and RPR+. The relationship between $\gamma \delta$ T-cell activation and neutrophils was analyzed. There were no correlations between the frequencies of $\mathrm{CD} 8^{+}$ (A), $\mathrm{HLA}_{-} \mathrm{DR}^{+}$(B), and CD38+HLA-DR+ (C) $\gamma \delta$ T cells and the percentage of neutrophils in all HIV-1-infected patients with $\operatorname{RPR}^{-}(\mathbf{\bullet})$ and $\operatorname{RPR}^{+}(\mathbf{\bullet})$.

Correlations were calculated by using Spearman's rank correlation. $P<0.05$ was considered to be statistically significant. RPR, rapid plasma reagin.

18. Albin JS, Harris RS. Interactions of host APOBEC3 restriction factors with HIV-1 in vivo: implications for therapeutics. Expert Rev Mol Med (2010) 12:e4. doi:10.1017/S1462399409001343

19. Wang C, Zhu L, Gao Z, Guan Z, Lu H, Shi M, et al. Increased interleukin-17 in peripheral blood and cerebrospinal fluid of neurosyphilis patients. PLoS Negl Trop Dis (2014) 8:e3004. doi:10.1371/journal.pntd.0003004

20. Pastuszczak M, Jakiela B, Wielowieyska-Szybinska D, Jaworek AK, Zeman J, Wojas-Pelc A. Elevated cerebrospinal fluid interleukin-17A and interferon-gamma levels in early asymptomatic neurosyphilis. Sex Transm Dis (2013) 40:808-12. doi:10.1097/OLQ.0000000000000024

21. Chien YH, Meyer C, Bonneville M. Gammadelta T cells: first line of defense and beyond. Annu Rev Immunol (2014) 32:121-55. doi:10.1146/ annurev-immunol-032713-120216

22. Mao Y, Yin S, Zhang J, Hu Y, Huang B, Cui L, et al. A new effect of IL-4 on human gammadelta $\mathrm{T}$ cells: promoting regulatory Vdeltal $\mathrm{T}$ cells via IL-10 production and inhibiting function of Vdelta2 T cells. Cell Mol Immunol (2016) 13:217-28. doi:10.1038/cmi.2015.07

23. Liuzzi AR, McLaren JE, Price DA, Eberl M. Early innate responses to pathogens: pattern recognition by unconventional human T-cells. Curr Opin Immunol (2015) 36:31-7. doi:10.1016/j.coi.2015.06.002

24. Pauza CD, Poonia B, Li H, Cairo C, Chaudhry S. Gammadelta T cells in HIV disease: past, present, and future. Front Immunol (2015) 5:687. doi:10.3389/ fimmu.2014.00687

25. Li H, Chaudhry S, Poonia B, Shao Y, Pauza CD. Depletion and dysfunction of Vgamma2Vdelta2 $\mathrm{T}$ cells in HIV disease: mechanisms, impacts and therapeutic implications. Cell Mol Immunol (2013) 10:42-9. doi:10.1038/ cmi.2013.13

26. Li Z, Jiao Y, Hu Y, Cui L, Chen D, Wu H, et al. Distortion of memory Vdelta2 gammadelta $\mathrm{T}$ cells contributes to immune dysfunction in chronic HIV infection. Cell Mol Immunol (2015) 12:604-14. doi:10.1038/ cmi.2014.77

27. Stary G, Klein I, Bruggen MC, Kohlhofer S, Brunner PM, Spazierer D, et al. Host defense mechanisms in secondary syphilitic lesions: a role for IFNgamma-/IL-17-producing CD8+ T cells? Am J Pathol (2010) 177:2421-32. doi:10.2353/ajpath.2010.100277

28. Huang X, Lodi S, Fox Z, Li W, Phillips A, Porter K, et al. Rate of CD4 decline and HIV-RNA change following HIV seroconversion in men who have sex with men: a comparison between the Beijing PRIMO and CASCADE cohorts. JAcquir Immune Defic Syndr (2013) 62:441-6. doi:10.1097/ QAI.0b013e31827f5c9a

29. Hubert JB, Burgard M, Dussaix E, Tamalet C, Deveau C, Le Chenadec J, et al. Natural history of serum HIV-1 RNA levels in 330 patients with a known date of infection. The SEROCO Study Group. AIDS (2000) 14:123-31.

30. Cohen MS, Gay CL, Busch MP, Hecht FM. The detection of acute HIV infection. J Infect Dis (2010) 202(Suppl 2):S270-7. doi:10.1086/655651

31. Fiebig EW, Wright DJ, Rawal BD, Garrett PE, Schumacher RT, Peddada L, et al. Dynamics of HIV viremia and antibody seroconversion in plasma donors: implications for diagnosis and staging of primary HIV infection. AIDS (2003) 17:1871-9. doi:10.1097/00002030-200309050-00005

32. Janier M, Hegyi V, Dupin N, Unemo M, Tiplica GS, Potocnik M, et al. 2014 European guideline on the management of syphilis. JEur Acad Dermatol Venereol (2014) 28:1581-93. doi:10.1111/jdv.12734

33. Chen P, Su B, Zhang T, Zhu X, Xia W, Fu Y, et al. Perturbations of monocyte subsets and their association with $\mathrm{T}$ helper cell differentiation in acute and chronic HIV-1-infected patients. Front Immunol (2017) 8:272. doi:10.3389/ fimmu.2017.00272

34. Lu X, Su B, Xia H, Zhang X, Liu Z, Ji Y, et al. Low double-negative CD3+CD4-CD8- $T$ cells are associated with incomplete restoration of 
CD4+ T cells and higher immune activation in HIV-1 immunological nonresponders. Front Immunol (2016) 7:579. doi:10.3389/fimmu.2016.00579

35. Okoye AA, Picker LJ. CD4(+) T-cell depletion in HIV infection: mechanisms of immunological failure. Immunol Rev (2013) 254:54-64. doi:10.1111/ imr. 12066

36. Douek DC, Picker LJ, Koup RA. T cell dynamics in HIV-1 infection. Annu Rev Immunol (2003) 21:265-304. doi:10.1146/annurev.immunol.21. 120601.141053

37. Di Mitri D, Azevedo RI, Henson SM, Libri V, Riddell NE, Macaulay R, et al. Reversible senescence in human CD4+CD45RA+CD27- memory $\mathrm{T}$ cells. J Immunol (2011) 187:2093-100. doi:10.4049/jimmunol.1100978

38. Caccamo N, La Mendola C, Orlando V, Meraviglia S, Todaro M, Stassi G, et al. Differentiation, phenotype, and function of interleukin-17-producing human Vgamma9Vdelta2 T cells. Blood (2011) 118:129-38. doi:10.1182/ blood-2011-01-331298

39. Ribot JC, deBarros A, Pang DJ, Neves JF, Peperzak V, Roberts SJ, et al. CD27 is a thymic determinant of the balance between interferon-gamma- and interleukin 17-producing gammadelta T cell subsets. Nat Immunol (2009) 10:427-36. doi:10.1038/ni.1717

40. Cua DJ, Tato CM. Innate IL-17-producing cells: the sentinels of the immune system. Nat Rev Immunol (2010) 10:479-89. doi:10.1038/nri2800

41. Shibata K, Yamada H, Hara H, Kishihara K, Yoshikai Y. Resident Vdelta1+ gammadelta $\mathrm{T}$ cells control early infiltration of neutrophils after Escherichia coli infection via IL-17 production. J Immunol (2007) 178:4466-72. doi:10.4049/ jimmunol.178.7.4466

42. Stark MA, Huo Y, Burcin TL, Morris MA, Olson TS, Ley K. Phagocytosis of apoptotic neutrophils regulates granulopoiesis via IL-23 and IL-17. Immunity (2005) 22:285-94. doi:10.1016/j.immuni.2005.01.011

43. Li Z, Li W, Li N, Jiao Y, Chen D, Cui L, et al. Gammadelta T cells are involved in acute HIV infection and associated with AIDS progression. PLoS One (2014) 9:e106064. doi:10.1371/journal.pone.0106064

44. Sabbione F, Gabelloni ML, Ernst G, Gori MS, Salamone G, Oleastro M, et al. Neutrophils suppress gammadelta T-cell function. Eur J Immunol (2014) 44:819-30. doi:10.1002/eji.201343664

45. Zhu A, Han $\mathrm{H}$, Zhao H, Hu J, Jiang C, Xie F, et al. Increased frequencies of Th17 and Th22 cells in the peripheral blood of patients with secondary syphilis. FEMS Immunol Med Microbiol (2012) 66:299-306. doi:10.1111/ j.1574-695X.2012.01007.x

46. Vantourout P, Hayday A. Six-of-the-best: unique contributions of gammadelta T cells to immunology. Nat Rev Immunol (2013) 13:88-100. doi:10.1038/ nri3384

47. Bonneville M, O'Brien RL, Born WK. Gammadelta T cell effector functions: a blend of innate programming and acquired plasticity. Nat Rev Immunol (2010) 10:467-78. doi:10.1038/nri2781

48. Kalyan S, Chandrasekaran V, Quabius ES, Lindhorst TK, Kabelitz D. Neutrophil uptake of nitrogen-bisphosphonates leads to the suppression of human peripheral blood gammadelta T cells. Cell Mol Life Sci (2014) 71:2335-46. doi:10.1007/s00018-013-1495-x

49. Coffelt SB, Kersten K, Doornebal CW, Weiden J, Vrijland K, Hau CS, et al. IL-17-producing gammadelta $\mathrm{T}$ cells and neutrophils conspire to promote breast cancer metastasis. Nature (2015) 522:345-8. doi:10.1038/ nature 14282

50. Zheng NN, McElrath MJ, Sow PS, Mesher A, Hawes SE, Stern J, et al. Association between peripheral gammadelta T-cell profile and disease progression in individuals infected with HIV-1 or HIV-2 in West Africa. J Acquir Immune Defic Syndr (2011) 57:92-100. doi:10.1097/QAI.0b013e318215a877

51. Arroll TW, Centurion-Lara A, Lukehart SA, Van Voorhis WC. T-Cell responses to Treponema pallidum subsp. pallidum antigens during the course of experimental syphilis infection. Infect Immun (1999) 67:4757-63.

52. Fay NS, Larson EC, Jameson JM. Chronic inflammation and gammadelta T cells. Front Immunol (2016) 7:210. doi:10.3389/fimmu.2016.00210

53. Deniger DC, Moyes JS, Cooper LJ. Clinical applications of gamma delta T cells with multivalent immunity. Front Immunol (2014) 5:636. doi:10.3389/ fimmu.2014.00636
54. Qin G, Liu Y, Zheng J, Xiang Z, Ng IH, Malik Peiris JS, et al. Phenotypic and functional characterization of human gammadelta $\mathrm{T}$-cell subsets in response to influenza A viruses. J Infect Dis (2012) 205:1646-53. doi:10.1093/infdis/ jis 253

55. Utay NS, Hunt PW. Role of immune activation in progression to AIDS. Curr Opin HIV AIDS (2016) 11:131-7. doi:10.1097/COH.0000000000000242

56. Kelesidis T. The cross-talk between spirochetal lipoproteins and immunity. Front Immunol (2014) 5:310. doi:10.3389/fimmu.2014.00310

57. Radolf JD, Arndt LL, Akins DR, Curetty LL, Levi ME, Shen Y, et al. Treponema pallidum and Borrelia burgdorferi lipoproteins and synthetic lipopeptides activate monocytes/macrophages. J Immunol (1995) 154:2866-77.

58. Aceto L, Karrer U, Grube C, Oberholzer R, Hasse B, Presterl E, et al. [Primary HIV-1 infection in Zurich: 2002-2004]. Praxis (Bern 1994) (2005) 94:1199-205. doi:10.1024/0369-8394.94.32.1199

59. Bolz DD, Sundsbak RS, Ma Y, Akira S, Kirschning CJ, Zachary JF, et al. MyD88 plays a unique role in host defense but not arthritis development in Lyme disease. J Immunol (2004) 173:2003-10. doi:10.4049/jimmunol.173.3.2003

60. Benhnia MR, Wroblewski D, Akhtar MN, Patel RA, Lavezzi W, Gangloff SC, et al. Signaling through CD14 attenuates the inflammatory response to Borrelia burgdorferi, the agent of Lyme disease. J Immunol (2005) 174:1539-48. doi:10.4049/jimmunol.174.3.1539

61. Kalyan S, Kabelitz D. When neutrophils meet T cells: beginnings of a tumultuous relationship with underappreciated potential. Eur J Immunol (2014) 44:627-33. doi:10.1002/eji.201344195

62. Amatya N, Garg AV, Gaffen SL. IL-17 signaling: the Yin and the Yang. Trends Immunol (2017) 38:310-22. doi:10.1016/j.it.2017.01.006

63. Hagen CE, Kamionek M, McKinsey DS, Misdraji J. Syphilis presenting as inflammatory tumors of the liver in HIV-positive homosexual men. Am J Surg Pathol (2014) 38:1636-43. doi:10.1097/PAS.0000000000000264

64. Freundt-Revilla J, Maiolini A, Carlson R, Beyerbach M, Rentmeister K, Flegel $\mathrm{T}$, et al. Th17-skewed immune response and cluster of differentiation 40 ligand expression in canine steroid-responsive meningitis-arteritis, a large animal model for neutrophilic meningitis. J Neuroinflammation (2017) 14:20. doi:10.1186/s12974-016-0784-3

65. Shilaih M, Marzel A, Braun DL, Scherrer AU, Kovari H, Young J, et al. Factors associated with syphilis incidence in the HIV-infected in the era of highly active antiretrovirals. Medicine (Baltimore) (2017) 96:e5849. doi:10.1097/ MD.0000000000005849

66. St Leger AJ, Desai JV, Drummond RA, Kugadas A, Almaghrabi F, Silver P, et al. An ocular commensal protects against corneal infection by driving an interleukin-17 response from mucosal gammadelta T cells. Immunity (2017) 47:148-58.e5. doi:10.1016/j.immuni.2017.06.014

67. Khairallah C, Dechanet-Merville J, Capone M. Gammadelta T cell-mediated immunity to cytomegalovirus infection. Front Immunol (2017) 8:105. doi:10.3389/fimmu.2017.00105

68. Couzi L, Pitard V, Moreau JF, Merville P, Dechanet-Merville J. Direct and indirect effects of cytomegalovirus-induced gammadelta $\mathrm{T}$ cells after kidney transplantation. Front Immunol (2015) 6:3. doi:10.3389/fimmu.2015.00003

69. Conti HR, Peterson AC, Brane L, Huppler AR, Hernandez-Santos N, Whibley N, et al. Oral-resident natural Th17 cells and gammadelta T cells control opportunistic Candida albicans infections. J Exp Med (2014) 211:2075-84. doi:10.1084/jem.20130877

Conflict of Interest Statement: The authors declare that the research was conducted in the absence of any commercial or financial relationships that could be construed as a potential conflict of interest.

Copyright $\odot 2017 \mathrm{Li}, \mathrm{Lu}, \mathrm{Hu}$, Luo, Jiang, Wu, Gao, Yan, Zhang, Song, Huang, Mou, Su and Zhang. This is an open-access article distributed under the terms of the Creative Commons Attribution License (CC BY). The use, distribution or reproduction in other forums is permitted, provided the original author(s) or licensor are credited and that the original publication in this journal is cited, in accordance with accepted academic practice. No use, distribution or reproduction is permitted which does not comply with these terms. 